\title{
The Search for Tsunami Evidence in the Geological and Archaeological Records, With a Focus on Japan
}

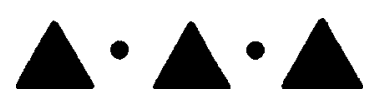

Gina L. BARneS

\begin{abstract}
Tsunami damage to archaeological sites in Japan has been recognized since the 1980s, but the Great Tōhoku-oki Earthquake and tsunami of 11 March 2011 stimulated geologists and archaeologists to find evidence of previous tsunami in Japan, investigate the responses of earlier inhabitants to tsunami, and assess the probability of future occurrences. Excavated sites on the Sendai Plain, partially inundated in this recent tsunami, have been crucial in this endeavor, with recovered data at times contradicting historical sources. Great progress has been made in the science of identifying tsunami deposits and understanding their nature and distribution, aiding in their recognition at archaeological sites. This article provides an introduction to the nature of tsunami waves and their causes, resources available for studying past tsunami worldwide, and difficulties in identifying tsunami sediments. Seventeen case studies of sites where tsunami deposits have been investigated throughout the Japanese and Ryukyu archipelagos are presented. Tsunami can be included within my conception of 'tectonic archaeology', archaeology that must methodologically deal with the influence of plate tectonics on the islands. Earthquakes, volcanoes, and most tsunami relate to the subduction zone setting of Japan; thus, to fully understand the site remains of previous tectonically derived disasters demands knowledge of plate tectonics, seismology, volcanology, sedimentology, and wave physics among others. Integrating these spheres of knowledge into archaeological research opens new avenues of interpretation, including understanding why many Middle Yayoi settlements on the Sendai Plain were abandoned, not to be reoccupied for 400 years. KEYwORDs: tsunami, Japan, tsunami archaeology, Japanese archaeology, disaster archaeology, tectonic archaeology.
\end{abstract}

\section{FROM TECTONIC ARCHAEOLOGY TO DISASTER ARCHAEOLOGY}

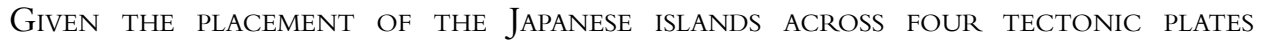
SEPARATED BY TWO PLATE SUBDUCTION ZONES, it is hardly surprising that tectonic forces have acted on past as well as present inhabitants (Barnes 2015a). Earthquakes, volcanic eruptions, and most tsunami have tectonic origins. The first two of these have given

Gina L. Barnes, Professor Emeritus of Durham University, is currently a Professorial Research Associate at the Department of History of Art and Archaeology and the Japan Research Centre, SOAS University of London, an Affiliate of Earth Sciences at Durham University, and a Fellow of the Geological Society of London. 
rise to specialist archaeological subdisciplines in Japan: jishin kōkogaku 地震考古学 or Earthquake Archaeology was named by geomorphologist Sangawa Akira (Sangawa 1988) and kazanbai kōkogaku 火山灰考古学 or TephroArchaeology was coined by two volcanologists Arai Fusao and Machida Hiroshi (Arai 1993). A third may well be developing: tsunami kōkogaku 津波考古学, or Tsunami Archaeology, in parallel with the new field of Tsunami Geology (Goto et al. 2014). After the earthquake and tsunami event of 11 March 2011 in Japan, the Tohoku Tsunami Joint Survey Group was formed, involving more than 300 Japanese and international geologists and engineers (Sato 2015). Although their purposes differ, geologists and archaeologists often work on the same sites or in collaboration to identify past tsunami (e.g., Ogura 2016). Geologists usually assess risk for damage mitigation, while archaeologists investigate past human responses to tsunami. ${ }^{1}$

There is now a movement in Japan to combine these interrelated subdisciplines into a more encompassing Disaster Archaeology that goes beyond tectonic causes to include all sorts of natural disasters (Okamura 2015; Okamura et al. 2013; Saino 2012b). A Disaster Archaeology database compiling information from published site reports is currently being developed at the Nara Research Institute for Cultural Properties (Nara Bunkazai Kenkyūjo, abbreviated as Nabunken) (Okamura 2015:251). These efforts at database construction by Nabunken close the circle on Shimoyama's attempts in the late 1990s and early 2000s to promote the field of Disaster Archaeology and present on the archaeology of natural disasters at World Archaeology Congresses (WAC4 in 1999, WAC5 in 2003) (Shimoyama 1997, 2002a, $2002 b$; Torrence and Grattan 2002). These newly developing subdisciplines contrast with Gould's (2007) proposal to deal with current disasters and recover data from them by aligning with forensic anthropology. Meanwhile, Schlanger, Nespoulous, and Demoule (2016) distinguish "disaster-led archaeology" from "developer-led archaeology." Although both these approaches fall into the realm of "rescue" (a.k.a. "preventive") archaeology, the former refers to the dramatic increase in archaeological excavations necessitated by recovery and re-building efforts. Archaeologists also bear the burden of preserving the memory of natural disasters for future generations in the form of disaster museums.

Shimoyama (2002a) set out parameters for defining and assessing the nature and extent of disasters - whether caused by humans or natural processes - and assessing human reactions to them. He defines a disaster as an event that directly or indirectly has human victims, while avoiding the point that when plant and animal communities are subject to disasters, it can have long-term, possibly delayed, effects on human communities. Although he admits that human reactions to similar events can be astoundingly variable, Shimoyama emphasizes that "it is valuable and important to establish a number of elements that are common to all cases and to propose a standard framework for their analysis" (2002a:26). He specifies six topics that need addressing: initiation, immediate causes, local conditions, damages, assessment, and actions.

Scale is another important concern in studying disasters. Wholesale abandonment of sites and human demise are often treated under "collapse" or "catastrophe" theory (Diamond 2011; Keys 1999), but societies often meet and rise above periodic damage and can even thrive in disaster-prone areas. Force (2015) hypothesizes that one reason the great Mediterranean and Himalayan societies became foci of civilization was their location on the tectonic borders of the African/Eurasian/Indian plates. These borders provided trade routes and fertile valleys for settlement while the repetition of 
devastating earthquakes forced innovation and recovery. In contrast with inland earthquake zones, tsunami usually occur at long intervals and their effects are usually limited to narrow coastal strips. Before the advent of vulnerable modern infrastructure, the numbers of people and villages in coastal areas were often matched or exceeded by inland populations, so that entire cultures and civilizations were not at risk of total destruction. Any loss of human life is a tragedy, however. Disaster archaeologists hope to prevent worse losses in the future by understanding past disasters. Current research in disaster archaeology tends to focus on past and present human reactions in order to predict and prepare for future disasters. While these are laudable goals, this article deals with the basics. That is, following Shimoyama, it addresses how to define and assess disasters resulting from tsunami in the stratigraphic record. This is not an easy task, because the scientific parameters of disaster are not yet well-understood in the archaeological community.

The cases discussed here demonstrate that human behavior is visible in tsunami events. These case studies form a jumping off point for further analyses. Subsequent analyses must not start with the question "What happened?" but with "What happened next?" Was the tsunami a simple occurrence with limited effect or was it an event that changed the course of history (Sewell 2005)? Did people simply recover and go back to normal? Or were their social, political, or subsistence systems changed by this disruption of normal life? Goff and Nunn (2016) propose that tsunami is one type of environmental agent forcing cultural change. One avenue for investigating such change in Japan is offered in the conclusions here.

\section{TSUNAMI ARCHAEOLOGY}

Japan is a good place to start a discussion on Tsunami Archaeology. The entire Pacific seaboard of Japan is vulnerable to Pacific Ocean tsunami. The effects of these tsunami sometimes intrude into the Inland Sea, though the waves developed there have slowed down and do not strike orthogonally. Even the Japan Sea has a record of tsunami (Hamasaki et al. 2012). For example, the 1983 Nihonkai-Chūbu tsunami scattered the concrete tetrapods that lined the shore for erosion control onto the land (Imamura n.d.). The coastal plains (totaling no more than 14 percent of the archipelago's land area) have provided the majority of flat land for housing the population in Japan since the early centuries B.C. These plains are at the mercy of tsunami activity. The effect of tsunami on modern society was well illustrated in 2011, when the devastation to Japan's Sanriku coast in Tōhoku had global repercussions (Kaner et al. 2011) (Fig. 1). In pre-industrial society, damage was not as widespread. Nevertheless, archaeological excavations have revealed that economies suffered and settlements were disrupted, with presumed loss of life.

As was illustrated by the 2004 Indian Ocean tsunami, Japan is not the only country affected by destructive tsunami. Coastal areas around Europe, the Pacific Rim, and Indian Ocean are all at risk. Geologists have been studying tsunami deposits for some time (see references in Dominey-Howes et al. 2006 and Matsumoto et al. 2016; also see Fujiwara 2015; Shiki et al. 2008), but attention to tsunami deposits in Japanese archaeological sites only began in the late 1980s (Goto et al. 2014; Saino 2015b) and on the northwestern coast of North America in the 1990s (Goff and McFadgen 2001, 2003). Such archaeological investigations have become more common after the turn of the millennium. Around the same time, scholars in New Zealand began dealing with tsunami deposits in 


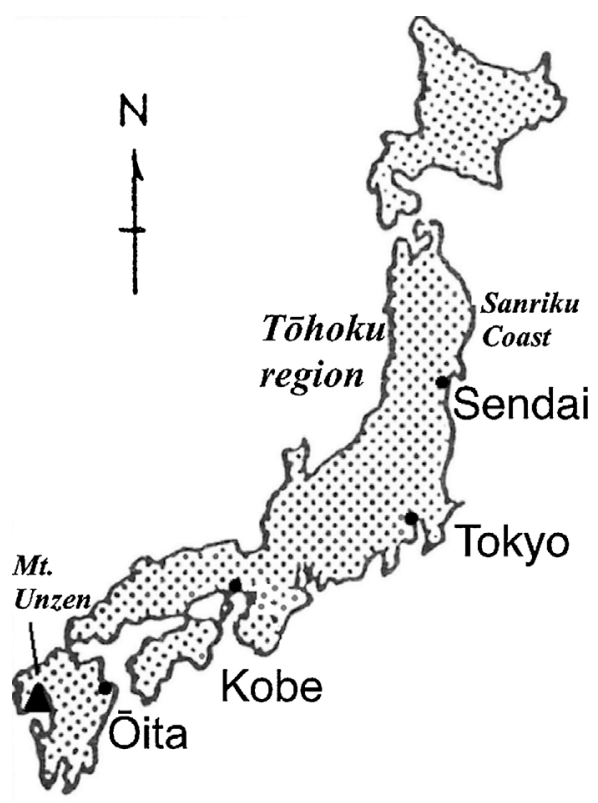

Fig. 1. Map of Japan and major geographical locations mentioned in the text.

archaeological sites (Goff et al. 2001; Goff and McFadgen 2001, 2003; McFadgen and Goff 2007). New Zealand archaeologists deal not only with individual site histories but also with general methodology. The New Zealand studies thus form an important body of comparative material for Japan, though the historical depth and complexities of the archaeological records in the two countries are quite different.

This article is a first attempt to map out the incipient field of Tsunami Archaeology from a Japanese viewpoint. The few geological and archaeological investigations that have been conducted are examined and some conclusions on human behavior are drawn from these case studies. These investigations are not comprehensive, but are indicative of the kinds of research being carried out today.

\section{DEFINING AND MEASURING TSUNAMI}

\section{Definition}

Tsunami is a Japanese word combining two roots, $t s u$ (harbor) and nami (wave). The word first appeared written in modern characters (津波) in a 1612 document titled Sunpuki 駿府記 (Records of the Sunpu Castle), which recorded a tsunami in 1611 (Cartwright and Nakamura 2008). Atwater and colleagues (2005:47) relate that the word entered the English language via a story about a tsunami written in 1897 by Japan-resident Irish author Lafcadio Hearn titled "The Living God." Though often given the plural suffix '-s' in English texts, Japanese words do not take a plural form; tsunami should be treated as a collective noun to mean one or many. English speakers sometimes refer to tsunami as "tidal waves" (Kaner 2011). Though they can interact with tides, tsunami comprise a different phenomenon. 


\section{Causes}

Tsunami are generated by a variety of sometimes interrelated processes including volcanoes, earthquakes, and landslides (Fritz et al. 2009; Lockridge 1990; Pendick 1998) (Fig. 2). Lockridge (1990) notes that the eruption of underwater gases may even cause tsunami in lakes and warns that landslides occur repeatedly in certain locations. Although the causes of tsunami that are not generated by earthquakes are difficult to decipher, data from the National Oceanic and Atmospheric Administration (NOAA) have enabled researchers to estimate percentages of tsunami that arose from each geologic process over the past 4000 years (Goto 2015b) (Table 1).

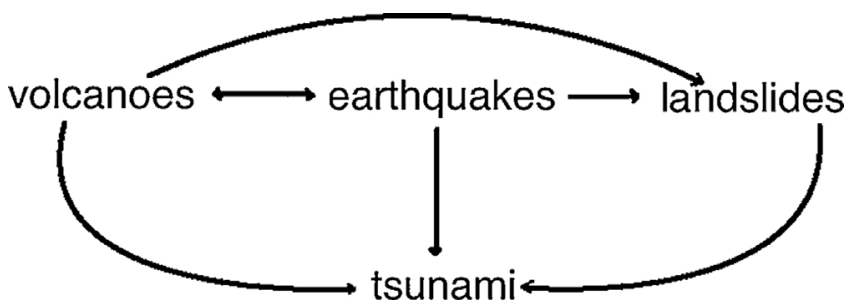

Fig. 2. Relationships between different tectonic activities and their possible repercussions (after Lockridge 1990:404, Fig. 1). Note that most arrows are unidirectional, but volcanic eruptions and earthquakes are inter-sensitive and can cause each other. Tsunami have three possible tectonic causes.

Table i. Multiple causes of tSunami

\begin{tabular}{lll}
\hline$\%$ & \multicolumn{1}{c}{ CAUSE } & DESCRIPTION \\
\hline 76.2 & Earthquakes & $\begin{array}{c}\text { Tectonic deformation (a sudden drop or rise in the ocean floor } \\
\text { and the water column above it) }\end{array}$ \\
10.5 & Undetermined & -
\end{tabular}

Source: Compiled from Goto (2015b), Lockridge (1990), and Satake (2007). 


\section{Measurements}

Multidimensional measurements of tsunami waves include depth, height, distance, speed, and number of waves. Further measurements are taken once the tsunami hits land, including inundation level and distance. Finally, the force and destructive power of tsunami are measured in various ways, with nonseismogenic tsunami often holding records (Table 2). For archaeological work, the measurements on land are particularly important. Inundation level and distance should be clearly distinguished from run-up (maximum height from sea level obtained on land). The run-up is usually the most impressive part of the tsunami, but it is often transient and localized. For example, the 2011 tsunami caused by the Great Tōhoku-oki Earthquake reached a run-up height of $40 \mathrm{~m}$ at Ofunato (Dunbar et al. 2013:117). A similar run-up height of $38 \mathrm{~m}$ was attained by the 1896 Meiji Sanriku tsunami (Satake 2007:487).

All these measurements are somewhat determined by the topography. If a tsunami wave enters the mouth of a river leading into a steep-sided valley, it will be funneled up to higher levels with less horizontal extent. If a wave strikes a beach bordered by dunes

TABle 2. WAYS OF MEASURING TSUNAMI AND SOME OF THE RECORD HOLDERS OF LARGE EVENTS

\begin{tabular}{|c|c|}
\hline MEASUREMENT CRITERION & DESCRIPTION \\
\hline Wave measurements & $\begin{array}{l}\text { Depth from sea floor to sea surface (changes as the wave passes over } \\
\text { various sea floor structures) } \\
\text { Distance between wave peaks (shortens when approaching land) } \\
\text { Height of wave from trough to peak (double amplitude; amplitude } \\
\text { increases when approaching land) (Satake 2007:490) } \\
\text { Speed of travel } \\
\text { Number of waves in wave train }\end{array}$ \\
\hline Measurements on land & $\begin{array}{l}\text { Inundation level is the height of the wave measured from tide level at the } \\
\text { time; flow depth is depth of wave on land } \\
\text { Run-up of a tsunami is measured as the maximum height from sea level } \\
\text { attained on land, which may exceed that of the inundation level } \\
\text { Inundation distance is how far the waves reach inland }\end{array}$ \\
\hline Record holders & $\begin{array}{l}\text { Oldest recognized tsunami occurred } 3.5 \text { billion years ago, covering all of } \\
\text { the small continental plates that existed at the time except for the } \\
\text { highest mountain tops (Glickson 2004) } \\
\text { Highest modern run-up reached by a tsunami wave on land was } 524 \mathrm{~m} \text { in } \\
\text { Lituya Bay, Alaska in 1958, when an earthquake dislodged } 30 \text { million } \\
\mathrm{m}^{3} \text { ( } 90 \text { million tons) of rock forming a landslide into the bay and a } \\
\text { run-up on the opposite hill spur (Fritz et al. 2009); the run-up only } \\
\text { affected one hillside, but the trees were stripped along the headlands up } \\
\text { to } 520 \mathrm{~m} \text { (Satake 2007:487) } \\
2004 \text { Indian Ocean tsunami resulted in the greatest loss of life, with } \\
\text { 350,000 estimated deaths (Athukorala and Resosudarmo 2005) } \\
\text { Previously, the most deadly tsunami in recorded history was generated by } \\
\text { the landslide accompanying the } 1833 \text { Krakatau eruption; 36,000 deaths } \\
\text { occurred, "the majority from the tsunamis" (Pendick 1998) } \\
\text { Worldwide, about } 25 \% \text { of deaths in volcanic eruptions are due to tsunami } \\
\text { (Satake 2007:497) } \\
\text { 1960 Chilean earthquake at M9.5 was the largest ever recorded; its } \\
\text { tsunami affected the entire Pacific seaboard of Honshu and Shikoku }\end{array}$ \\
\hline
\end{tabular}

\footnotetext{
${ }^{a}$ Run-up height and inundation distance are both conditioned by topography. As the waves are squeezed into bays and river drainages, they get taller and therefore travel longer distances than they would have if they had exhausted themselves on open flat land.
} 
covered by stands of trees (common in Japan), the speed of the wave will be reduced. The reason tsunami were originally named 'harbor waves' is that they attain greater height when they are funneled into a harbor setting and resonate off enclosing land surfaces. Tsunami heights can be enhanced by other factors such as coincidence with high tides, spring (as opposed to neap) tides, or storm surges.

The extent of inundation is also increased when tsunami are combined with high tides, spring tides, or storm surges. Mean tide ranges vary greatly by location. Areas with low mean tide ranges may be less subject to tsunami inundation than areas with high mean tide ranges. If a tsunami coincides with a low tide, the extent of inundation is lessened, but if the tide is exceptionally high, the results of a tsunami can be devastating (Roberts 2005).

\section{Action}

A basic misunderstanding of the nature of tsunami waves has been perpetrated by the frequent reproduction of Hokusai's great wave woodblock print to signify a tsunami, when in fact it depicts a wind storm wave with a breaking crest (Cox 2001). Cox (2001) and Doughton (2005) speculate that this imagery may have contributed to many recent tsunami deaths in Indonesia and Thailand because people did not recognize the tsunami wave form. Instead of waves continually crashing onto a beach, tsunami are more likely to form a wall of water in a shallow coastal sea, then the wall moves straight inland to flood the land. ${ }^{2}$ To understand how this happens, a review of wave generation is in order.

Because most tsunami are caused by deformation of the ocean floor and the water column above it, tsunami waves can be thousands of feet deep in the ocean, down to the ocean floor (Pendick 1998). They can travel up to $710 \mathrm{~km}$ per hour in a $4000 \mathrm{~m}$ deep ocean (Satake 2007:502). The waves caused by such deformation spread in concentric circles, much like the ripples caused by throwing a stone into a pond, though much deeper.

As with major earthquakes, which are preceded by tremors and may have aftershocks, major tsunami rarely consist of only one wave but rather a series of waves in a wave train. Whether a wave impacts the coast as a trough or a peak depends on whether the seabed moved up or down in the earthquake (McFadgen 2007:25). Rather unusually, the rise of the ocean surface during the Great Tōhoku-oki Earthquake of 2011 did not result in successive wave formation on the landward side. Deep-ocean Assessment and Reporting of Tsunamis (DART) data from monitoring the ocean bottom using pressure recorders and satellite altimetry show that the waves spread seaward through the Pacific (Fine et al. 2013). In the open ocean, tsunami waves may have crests several miles apart. Such wave trains hit land one after another. As they approach shallow water near landfall, the wave crests rise to form a wall of water; they may break at the shoreline but do not rear up in the open sea like storm waves. Each tsunami wave in the train hits areas of the coast that have different characteristics. It is therefore difficult to generalize measurements for any single tsunami event because the results are different for each wave in each area.

\section{DOCUMENTING PAST TSUNAMI}

Until recent excavation by geologists or archaeologists, information about past tsunami has been limited to what could be observed by contemporaries. Although entire coastlines may have been subjected to tsunami wave trains, they were only documented in those areas where damage was recorded by literate people. As Goto (2015b) states and Atwater and colleagues (2005) discovered, the Japanese records are extremely 
important for understanding Pacific Ocean tsunami, both emanating from Japan and arriving in Japan. Japan has a written record of tsunami that extends back 1300 years, with the first historical mention of tsunami in A.D. 869 (Table 3). ${ }^{3}$ Archaeologically, tsunami deposits in Japan have been documented back to the prehistoric period, to 7300 cal. B.C., accompanying the eruption of the Kikai Caldera in Jomon times (14,000-400 B.C.) (Fujiwara et al. 2010; Maeno et al. 2006). ${ }^{4}$

The last few hundred years have given us the most information on tsunami disasters. Three past tsunami in 1792, 1960, and 2011 stand out as exceptionally destructive. The worst historical tsunami in Japan occurred in conjunction with the 1792 eruption of Mt. Mayu in the Unzen Volcanic Complex of western Kyushu, Japan. The eruption was followed by a lava dome collapse and debris flow into Ariake Bay. The landslide is estimated to have been $30 \mathrm{~m}$ thick at its front and containing 150 million $\mathrm{m}^{3}$ of sediments traveling at $100 \mathrm{~m} / \mathrm{s}$ (Miyamoto 2010). The landslide triggered tsunami along $77 \mathrm{~km}$ of coastline around the Ariake Sea, which resulted in approximately 15,000 deaths (Shiki et al. 2008:167; Smithsonian 2013). This record death toll was only superseded by the Great Tōhoku tsunami of 11 March 2011, now referred to as $3 / 11$ in Japan (spoken as san-ichi-ichi or three-one-one). It inundated about $500 \mathrm{~km}^{2}$ (Jaffe et al. 2011) and took approximately 18,500 lives (NOAA 2015). Although the $3 / 11$ tsunami was at first thought to have been caused exclusively by the earthquake, evidence has been found of a submarine landslide that may have caused the high runup (Tappin 2015). "Submarine slumping" has also been suggested for the less destructive Sanriku tsunami of 1986 (Satake 2007:495).

Despite having originated as far afield as Chile, the tsunami of 1960 devastated Japan. The Chilean tsunami provided data on house destruction, which is partial when

Table 3. Japanese Archaeological Periods and Dates of Tsunami Discussed in the Text

\begin{tabular}{|c|c|c|}
\hline PERIOD & DATE RANGE & TSUNAMI DATES \\
\hline Jōmon & $14,000-400$ B.C. & \\
\hline Incipient & $13,350-10,550$ в.с. & \\
\hline Initial (Earliest) & $10,550-5050$ в.с. & c. 7300 B.C. \\
\hline Early & $5050-3520$ в.С. & And four tsunami between 6000 and 3000 B.c. \\
\hline Middle & $3520-2470$ B.C. & \\
\hline Late & $2470-1250$ в.с. & \\
\hline Final (Latest) & $\begin{array}{l}1250-970 \text { в.с. (SW Japan) } \\
1250-400 \text { в.c. (NE Japan) }\end{array}$ & \\
\hline Yayoi & 1000 B.C. - A.D. 250 & \\
\hline Initial (Earliest) I & 1000-800 в.с. & \\
\hline Early II & $800-450$ в.с. & \\
\hline Middle III, IV & 450 B.C. - A.D. 50 & c. 100 B.C. \\
\hline Late V & A.D. $50-250$ & \\
\hline Kofun & A.D. $250-710$ & \\
\hline Early & A.D. $250-400$ & \\
\hline Middle & A.D. $400-500$ & \\
\hline Late & A.D. $500-710$ & \\
\hline Nara & A.D. $710-794$ & \\
\hline Heian & A.D. $794-1185$ & A.D. 869 \\
\hline Medieval & A.D. $1185-1603$ & \\
\hline Pre-Modern & A.D. $1603-1868$ & A.D. $1611,1700,1707,1792$ \\
\hline Modern & A.D. 1868 to present & A.D. 1960,2011 \\
\hline
\end{tabular}


tsunami height is less than $2 \mathrm{~m}$, but significant when more than $4 \mathrm{~m}$ (Satake 2007:492). This tsunami stimulated research into historical tsunami and resulted in the establishment of the Pacific Tsunami Warning System (PTWS). ${ }^{5}$

Two "historical conventional tsunami databases" have been compiled by the Novosibirsk Tsunami Laboratory (NTL) and the National Geophysical Data Center (NGDC)/NOAA (Joseph 2011:69). ${ }^{6}$ In 1997, a comprehensive "Integrated Tsunami Database for the World Ocean" (WinITDB/WLD) was begun as part of a joint International Union of Geodesy and Geophysics Tsunami Commission (IUGG-TC) and International Coordination Group for the Tsunami Warning System in the Pacific (ICG/ITSU) Project "Basic Pacific Tsunami Catalog and Database."7 The database was created and maintained by the NTL, providing an offline, stand-alone tool working on a Windows platform (WinITDB) which could be distributed on CDROM. The features on this database were last updated in 2005, but the content is now available online for the Atlantic, Mediterranean, and Pacific (the Pacific data only go back to 47 B.C.). These data can now be accessed online via the International Tsunami Information Center (ITIC) website. ${ }^{8}$ Data on Japan in this database were assessed by the Japan Meteorological Agency (JMA), producing 2500 additional records and 1200 corrections (Igarashi 2007).

The American NOAA houses the "National Geophysical Data Center/World Data Service (NGDC/WDS) Global Historical Tsunami Database, 2100 BC to present" (NGDC/WDS 2015). ${ }^{9}$ This consists of two databases for historical tsunami. The first covers more than 2400 tsunami source events and the second provides approximately 20,000 tsunami run-up measurements for the Atlantic, Indian, and Pacific oceans and for the Mediterranean and Caribbean seas. These databases can be searched online or downloaded in full. The NOAA/NGDC also collaborated with the ITIC to produce a map illustrating the general distribution of tsunami and death tolls around the world. ${ }^{10}$

Another database only covering the Japan region is available from Tōhoku University (TEL 2016). The "Japan Tsunami Trace Database" was compiled and is maintained by the Disaster Control Research Center (DCRC) in the Graduate School of Engineering of Tōhoku University and the Japan Nuclear Energy Safety Organization (JNES). ${ }^{11}$ Only 60 tsunami events from A.D. 1596 onward are included in this database. However, it also compiles data drawn from historic documents such as field surveys, research reports, and coastal policies that describe 25,664 "traces" (konseki 痕跡) of tsunami. Traces are marks left on buildings, trees, rocks, and so on that indicate run-up heights and inundation distances (Iwabuchi et al. 2012). The 3367 traces that are dated before 1887 are categorized as "historic tsunami" traces, while the 22,297 traces dated after 1888 (for which seismic data are available) are called "modern tsunami" traces (Iwabuchi et al. 2012). Of the modern tsunami traces, 15,079 date since the Chilean tsunami of 1960.

Although some aspects of the database website such as the section on tsunami deposits are still in the build stage, data began to be released in 2010. This database has the unusual feature of "reliability" assessments, carried out by a committee of experts (Satake 2007:488). Different scales of reliability of the collected data in categories A-D (from reliable to increasingly uncertain), $\mathrm{X}$ (unreliable), and $\mathrm{Z}$ (needs more investigation) were established for pre- and post-1960 events, based on the tsunami from Chile of that year (Iwabuchi et al. 2012: I_1327, Table 1 and I_1329, Table 8). From 2007, the committee has conducted quarterly reviews of the reliability of both the documentary/field evidence for tsunami and the database system. Despite 
considerable documentation of tsunami in the last 400 years, very few mentions are reliable. Published measurements show a trend toward historic tsunami trace reliability in categories $\mathrm{A}-\mathrm{B}$ at 14 percent and modern trace reliability in categories $\mathrm{A}-\mathrm{B}$ at 40 percent. Such low reliability leaves the field of tsunami research wide open for geologists and archaeologists to further assess tsunami deposits.

Obtaining information about historical earthquakes and tsunami is crucial for numerical analysis and modeling force levels and destructive potential (Furumura et al. 2011; Maeno and Imamura 2007; Maeno et al. 2006; Minoura et al. 2001; Satake 2007; Sato 2015; Shuto and Fujima 2009). Simulated data can be used to forecast the scale and nature of future events, as well as for estimating the strength of previous earthquakes and tsunami to account for past inundation and damage. Although this topic is beyond the scope of this paper, archaeological investigation of past tsunami is critical for improving risk assessment and means of mitigating destruction from future tsunami.

\section{TSUNAMI SEDIMENTARY EVIDENCE}

It appears that only tsunami waves greater than $5 \mathrm{~m}$ high generate a sedimentary signature. In some cases, tsunami do not leave any deposits at all; the waves may scour the surface rather than leave anything behind (McFadgen 2007:35). Where tsunami do leave deposits, they are "highly variable" (Satake 2007:492). The general geological consensus is that tsunami waves characteristically leave behind sheets of sand, gravel, or pebbles on inundated land (Costa et al. 2015; McFadgen and Goff 2007; Satake 2007:489). Marine sediments may also be laid down in freshwater lakes near the coast (Furumura et al. 2011; Sawai et al. 2008).

Boulders (particularly of coral), trees, and other debris (including human remains) can also be left by tsunami (Davies 2002). ${ }^{12}$ Some researchers have utilized physical attributes such as wave height, boulder weight, and elevation of deposit to distinguish boulders deposited by tsunami from those deposited by storms (Goff et al. 2012). For example, since tsunami waves last much longer than individual storm waves, Watanabe and colleagues (2015) devised a numerical scheme using initial wave height and transport distance as determined by wave period to investigate boulders left by a 1771 tsunami on Ishigaki Island (see case studies below).

If the earthquake was proximal, there is a tendency to assess tsunami-affected land as having been downwarped by the earthquake (Atwater et al. 2005). Subsidence due to volcanic eruption is also known (Lockridge 1990). Downwarping or subsidence increases tsunami hazard, as these processes allow waves to inundate more land. There are cases of co-seismic uplift rather than downwarping, however (Kitamura and Kobayashi 2014; McFadgen and Goff, 2007). Moreover, subsidence and uplift can occur simultaneously on different parts of the fault (Satake 2007:486). These uplifts and downwarps relax between earthquakes, making it difficult to assess sea levels before the tsunami occurred.

Sometimes immense amounts of sand are deposited along the shoreline to form a new beach. Where does the tsunami sand come from? It is common knowledge among coastal peoples that the sand on a beach may decrease or disappear entirely during winter storms. Heavy waves can pick up dune and beach sand and carry it out to sea. Tsunami wave trains then pick up sand deposits from fair-weather wave depths, the intertidal zone, beach, and even dunes, put the sand into suspension, and then lay some of the sand down during inundation, when tsunami waves cover previously dry land 
surfaces. The 2011 Tōhoku tsunami waves picked up sand from on-land beach ridges and sand ejected during earthquake liquefaction events in the paddy fields (Goto et al. 2011). Sand can also be deposited secondarily from dunes stripped of cover by tsunami waves and then eroded by the wind (McFadgen 2007:37, 234).

Recent work has demonstrated that the extent of sand deposits does not correlate with the extent of inundation. The 2011 Tōhoku tsunami laid down terminal sand deposits under $2 \mathrm{~m}$ of water, representing only 60 percent of the extent of inundation, and a 60 percent rule of thumb has been devised. This specifies that the proportion of the inundation distance covered by sand is about 60 percent. Beyond the sand, mud was deposited between 60 to 95 percent of the inundation distance, and beyond that, marine water left chemical constituents that could be retrieved for analysis only for several months after the tsunami waters had abated (Chagué-Goff et al. 2012). In wetland peat deposits, tsunami signatures include smaller grain sizes of sand, increased organic matter, and higher concentrations of iron or sulfur (McFadgen 2007:35). Thus, archaeologists must pay attention to more than sand layers in sites if they want to understand the devastating effects of marine water incursions.

\section{Identifying Previous Tsunami Deposits}

Since 2000, there has been considerable focus in the geological literature on problems in identifying tsunami deposits in the sedimentary record (Fujiwara 2015; Scheffers and Kelletat 2003; Shuto and Fujima 2009; Tappin 2007). Such sediments are fairly easily distinguishable from other types of sediments deposited on a plain that derive from seasonal riverine flooding (alluvium), flash floods, debris flows, volcanic tephra fall, and in Japan, seasonal loess deposits carried from the Asian continent (Saino 2012a:225; Yamada et al. 2016). Distinguishing tsunami deposits from eolian dune erosion (McFadgen 2007:37) or storm deposits is a great challenge. ${ }^{13}$ Nevertheless, there are biological (pollen, diatom, foram, shell), stratigraphic, and chemical signatures that separate them (Chagué-Goff et al. 2012; Morton et al. 2007a). Goff and McFadgen (2003) compiled a list of characteristics that can be used to differentiate tsunami deposits from other sorts of deposits (Table 4), but the potential for tsunami signatures to vary by event makes generalization difficult (Chagué-Goff et al. 2012; Costa et al. 2015; Dominey-Howes et al. 2006). ${ }^{14}$

One important distributional aspect is that sand is deposited differently by tsunami and storm waves (Morton et al. 2007b) (Fig. 3). Tsunami sands are widespread and drape the existing topography, while storm wave sand tends to settle in hollows in the limited area of breaking waves. Minoura and colleagues (2001:84) note that storms on the Tōhoku coast are generally erosive and "do not produce regionally extensive deposits of marine sand on the flood plain."

Because tsunami deposits are widespread and distinguishing them from storm deposits at any one site is difficult, a regional approach must be taken to distinguish tsunami from storm deposits. The regional approach that has been proposed for distinguishing tsunami deposits is similar to that being developed in Earthquake Archaeology (Barnes 2010; McFadgen and Goff 2007; Obermeier 1996). This approach hinges on the stipulation that evidence from one site is not enough to propose sedimentary changes, so widespread effects must be documented. Tsunami sand deposited on "residual soils" is easier to distinguish than tsunami sand deposited on "older sand" layers, so examining deposits in several contexts is useful (Davies 
DIAGNOSTIC CHARACTERISTICS OF TSUNAMI DEPOSITS

- particle/grain sizes range from boulders to coarse sand to fine mud

- sediments generally fine inland and upward within the deposit

- each wave in a wave train can potentially form a distinct sedimentary unit

- distinct upper and lower subunits (run-up and backwash) can often be identified

- lower contact is unconformable or erosional

- can contain intraclasts of reworked material

- often associated with loading structures at base of deposit

- marked changes in foraminifera (and other marine microfossils) assemblages

- pollen concentrations are often diluted

- increases in $\mathrm{Na}, \mathrm{S}, \mathrm{Cl}, \mathrm{Ca}, \mathrm{Mg}$ due to seawater inundation and/or high shell content

- shells and shell-rich units are often present

- often associated with buried vascular plant material and/or buried soil

- shell, wood, and less dense debris often found "rafted" near top of sequence

- often associated with reworked archaeological remains

- known local or distant tsunamigenic sources can be postulated or identified

Source: After Goff and McFadgen (2003:612, Table 2) with permission.

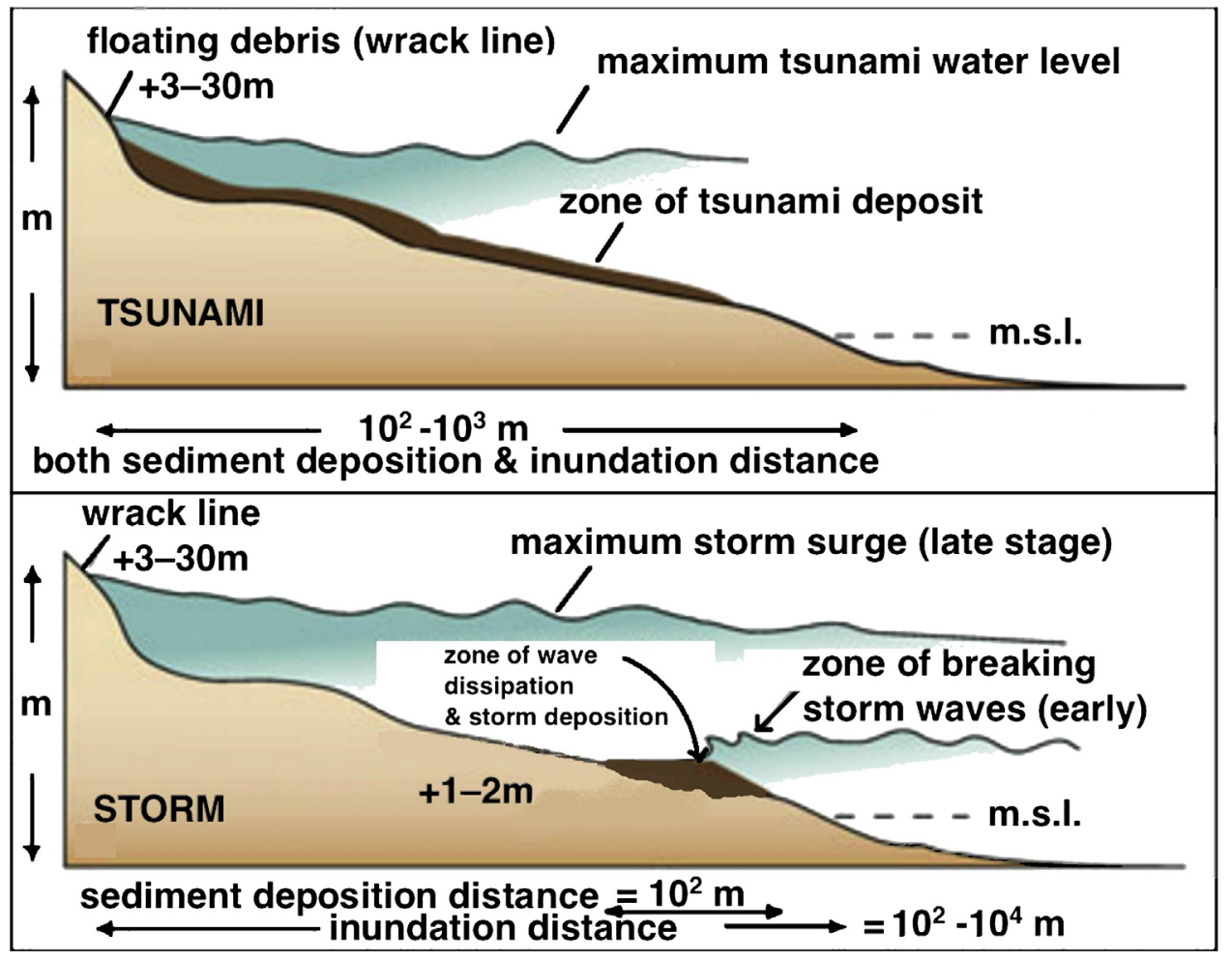

Fig. 3. Comparison of tsunami and storm wave sand deposits (modified from Morton et al. 2007b, USGS permission). 
2002:40). Tsunami deposits, high wave deposits, and alluvial deposits all have different areas of geographical distribution that can be used as clues in distinguishing them from storm deposits. The excavations at the Kutsukata site (discussed below), which stand as the best example of tsunami archaeology in Japan, and others on the Sendai Plain have confirmed the utility of broad-scale excavation and regional investigation in identifying tsunami deposits (Saino 2015b:245).

Archaeologists in Japan have developed limited criteria for investigating tsunami deposits. H. Matsumoto (2015:4) states that the following information is necessary to determine whether a certain deposit was made by a tsunami: grain size characteristics, age of deposit, distribution and nature of deposit, and the palaeotopography including the position of the ancient shoreline. Saino (2015b:243) outlines the following five steps for investigating tsunami:

1. Geologically distinguish tsunami deposits from alluvial and high wave [storm/typhoon] deposits.

2. Date tsunami deposits and cultural damage with both archaeological and geological dating techniques.

3. Reconstruct contemporaneous topography and coastline, in order to measure the distance of archaeological sites from the sea.

4. Estimate the spread of tsunami deposits and inundation distance.

5. Determine the cause of the tsunami, particularly if there was a proximate earthquake at the same time.

Historical documents that give the date and even the time of tsunami waves provide precise dating. As Saino (2012a, 2013, 2015a:7) cautions, however, it is important to confirm that these records are accurate with reference to archaeological finds. The discovery of tsunami deposits in archaeological sites is especially advantageous since cultural materials found in layers above and below tsunami sands can provide relative sandwiching dates. In off-site cases where such information is absent, there are several other methods of determining the date. One is using dendrochronology that can specify a certain calendar year depending on whether a tree died with tsunami inundation or lived briefly thereafter. Radiocarbon dates taken from organic matter in sediments above, below, or even within tsunami deposits are another technique, although close attention is needed to identify possible inbuilt (or pre-sample) age in case the organic matter is considerably older than the tsunami event (Gavin 2001; McFadgen 1982). Inbuilt ages can significantly distort dates, especially during the last millennium. In Japan, the sedimentary column often contains tephra from near or far volcanoes; identifying and dating the tephra can provide terminus post quem or terminus ante quem dates for tsunami deposits.

\section{CYCLICAL TSUNAMI AND RECOVERY}

Despite the terrible destruction by the 2011 tsunami to the Sanriku coast northeast of Sendai City in Miyagi Prefecture, the Sendai Plain has become a showcase for studying cyclical tsunami activity (Goto et al. 2015; Saino 2015b). The identification of stratigraphic layering of tsunami deposits on the Sendai Plain has revealed recurring mega-tsunami and accompanying earthquakes. Recovered deposits dated to 100 B.C., A.D. 869, and A.D. 2011 suggest that tsunami strike the coast roughly every thousand years. The first struck during the Middle Yayoi period (450 B.C. to A.D. 50), causing the abandonment of several village sites, which were not recolonized for another 400 years 
(Table 3). The second one struck in the traditional reign date of Jōgan 11 (i.e., A.D. 869) during the Heian period (A.D. 794-1185). This time, most damaged villages continued to be occupied, although some paddy fields were abandoned. A growing number of scientists consider the A.D. 869 tsunami a comparable forerunner to the March 2011 event. The 2011 tsunami not only partially covered the Sendai airport, but also forced the survivors of at least six coastal villages to be rehoused in a new town farther from the coast.

The modern and Middle Yayoi earthquakes and tsunami are assessed at similar magnitudes and extents, but the Joggan 11 earthquake was estimated at lesser strength (M8.3) (Minoura et al. 2001). It is notable that abandonment of affected areas has been a favored option for the stronger events, but Jogan-period peoples seem to have been able to weather the damage and were resilient in continuing their settlement of the plains (Saino 2015a:6-7). The difference between the Yayoi and Jogan responses may have been due to differences in organizational complexity. The Yayoi peoples in this area were subsistence agriculturalists living in presumably self-sufficient villages without a more regionally-integrated political context. This means that they had to depend on neighbors and relatives in dire times.

By the Heian period, the expanding state had established a provincial center, Tagajō Kokufu, and a branch of the national Buddhist temple network, Mutsu Kokubunji, at the northern edge of the Sendai Plain. Thus, not only was the Jogan tsunami and its 1000 death toll recorded by the local scribes, but help might have been available from government facilities to tide farmers over destruction of agricultural land. In ricegrowing areas, the addition of salts to paddy soils from seawater, not to mention any sand cover, is detrimental to crops. Salt seeps farther into sandy soils than clay soils, but leaches out more quickly. It is estimated that soils are unusable for at least a year after a tsunami, depending on the local precipitation rates (McFadgen 2007:233). Since paddy fields in Japan are underlain by a hardpan that prevents water from draining through the soil (to keep the crop inundated during the growing season), saltwater too will not leach out of the soils quickly.

Changes in settlement location often result in a change in subsistence, since coastal resources have been damaged or are no longer available. After the 3/11 tsunami in Japan, there was much discussion about moving coastal towns to upland locations; and the presence of historic markers of previous tsunami run-up or inundation levels, which had been disregarded in the interest of modern urbanization, became a sensational focus of the media (e.g., Fackler 2011). Although according to a 1954 Cultural Properties Law, archaeological investigation is demanded before construction, temporary housing was erected on high ground. However, many people preferred to return and rebuild their old settlements on the coast rather than move elsewhere. Building complete "new towns" was another alternative. For example, the survivors of six destroyed villages were resettled in the "new town" of Tama-ura Nishi, which was built only $3 \mathrm{~km}$ from the coast even though the inundation distance for the 3/11 tsunami had reached $5 \mathrm{~km}$ inland in places (Ishibashi 2015). Sako Architects suggested raising communities atop $40 \mathrm{~m}$ of rubble cushions (Gilhooly 2012). At Rikuzentakata, an area that bore heavy destruction from the $3 / 11$ tsunami, authorities have been stripping nearby mountains to provide landfill to raise parts of the town up on foundations high enough to avoid future inundations, although this practice is endangering archaeological resources (Guttenfelder and Hoshiko 2016). Such recourses were not available to prehistoric peoples, so the archaeological 
record instead speaks of site abandonment as the primary response to destructive tsunami.

Earlier tsunami sediments up to 3800 years old have been found in the stratigraphy of the Sendai Plain (Goto et al. 2011). Minoura and colleagues (2001) dated a lower sand layer to c. 910-670 B.C., which falls within the Tōhoku Final Jōmon phase (Table 3). Jōmon settlements were commonly located on high ground in the Tōhoku region. Perhaps residents were aware that tsunami periodically washed up the coast. Owing to high sea levels between 4000 and 2000 B.c. during the Holocene climatic optimum, and plains formation thereafter, it is unlikely that tsunami remains will be found for any time earlier than 2000 B.c., but tsunami evidence in Ōita Prefecture, Kyushu, has been assigned to the Kikai Caldera eruption in 7300 B.C. (Fujiwara et al. 2010). The effects of tsunami on available natural resources could have been disastrous for later Jōmon and other historical populations such as the Ainu who lived close to nature (Fukasawa 2015). As Goff and McFadgen (2001:159) recount for New Zealand, terrestrial, lacustrine, and marine food sources would have been lost and vegetation destroyed. Lakes and lagoons would have dried up, sediment would have infilled streams and rivers, and shellfish beds would have been smothered. Settlements and gardens at the bases of cliffs would have been vulnerable to landslides. Travel either on foot or by canoe would have been seriously impeded in the short term as a result of land sliding, fissuring, and the destruction of vegetation.

The plains of Japan, including Sendai, are subject to other natural disasters such as typhoons, earthquakes, floods, landslides, lahars, and volcanic extrusions. Moreover, although this matter needs further investigation, the beach ridges along the coast may correlate with previous earthquakes (McFadgen 2007:24). The effects of tsunami on the inhabitants both past and present must be separated from these other causes in order to assess the risk people face in future from sea incursions and salt-water inundation.

\section{TSUNAMI EXCAVATIONS IN JAPAN: CASE STUDIES}

The 2011 tsunami stimulated geologists to investigate palaeo-tsunami occurrence in greater depth using coring, geo-slicing, and test-trenching. Although the 2011 tsunami brought wide attention to past tsunami, excavations of tsunami deposits had been conducted before this. It has become a "matter of profound regret" that archaeologists did not publicize their findings widely enough to influence public policy for tsunami preparedness (Okamura et al. 2013:267). The recent tsunami of March 2011 has been compared above to the tsunami of A.D. 869 and to the Middle Yayoi tsunami in 100 B.C. Case studies of these and other tsunami are presented below, with the most recent first and progressing backward in time.

\section{Tōhoku Tsunami}

Sendai Plain Transect - An international team surveyed a transect across the Sendai Plain from coast to Sendai Airport to "document physical evidence of tsunami flow characteristics - such as debris in trees, high-water stains on buildings, and sedimentary deposits" (Jaffe et al. 2011:2). The transect site was chosen based on research on the tsunami of A.D. 869 that had also affected the Sendai Plain (Chagué-Goff et al. 2012; Jaffe et al. 2011). Jaffe, Richmond, and Gibbons (2011:4) caution, however, that "the 
relative magnitudes of the Jōgan and 2011 tsunamis cannot be inferred from the thickness of each deposit, which is affected by local topography as well as sediment grain size and tsunami flow speed." The deposits were assessed according to local topography, microtopography, flow directions, and water levels. Coring equipment (the geo-slicer) was used to assess sediment thickness, grain size, and sedimentary structures.

Along this transect, 2011 tsunami sand deposits extended $2.9 \mathrm{~km}$ inland, but mud deposits were found $4.65 \mathrm{~km}$ inland. However, markers of marine water such as sulfur (S) and chlorine $(\mathrm{Cl})$ were found $4.85 \mathrm{~km}$ inland, close to the maximum known inundation of more than $5 \mathrm{~km}$. S and $\mathrm{Cl}$ existed farther inland of any tsunamigenic sedimentation, but decreased over time via leaching by rainwater. Other elements such as strontium ( $\mathrm{Sr}$ ) and rubidium $(\mathrm{Rb})$ seem to be more persistent, since they were found in the lower deposits of the Jōgan tsunami of A.D. 869 (see below).

Minami Sōma-shi, Fukushima Prefecture - After the Tōhoku tsunami damaged the Fukushima nuclear reactor ponds in March 2011, the area around the reactor was evacuated. Since then, only basic activities such as removing rubble, repairing roads and dikes, and cutting grass in paddy fields have been carried out, so the tsunami deposits have been left undisturbed.

Ogura (2016) and his colleagues conducted a trenching project over an area $1.6 \mathrm{~km}$ $\mathrm{E} / \mathrm{W} \times 1.4 \mathrm{~km} \mathrm{~N} / \mathrm{S}$ of paddy fields adjoining the Odaka river east of the Odaka JR (Japan Railways) station. This land had reportedly sunk about $1 \mathrm{~m}$ after the earthquake and collected water after a heavy rain. Thirty test trenches, each $50-80 \mathrm{~cm}$ per side and 20-30 cm deep, were cut at $50 \mathrm{~m}$ intervals. Of these 30 trenches, 22 were cut on an $\mathrm{E} / \mathrm{W}$ transect $1135 \mathrm{~m}$ long, that is, along the axis of the incoming waves, and the other 8 were cut on three shorter orthogonal transects. The trenches were dug through the tsunami deposits to reach the level of previously cultivated paddy fields, though some trenches went slightly deeper.

Four basic strata were identified in this area, where the tsunami waves had been $10 \mathrm{~m}$ high:

Layer $0=$ recent deposits occurring after the tsunami

Layer $1=$ tsunami deposits, subdivided into three layers: $1 \mathrm{a} \leq 11 \mathrm{~cm}, 1 \mathrm{~b}$-upper $\leq 19 \mathrm{~cm}$,

$1 \mathrm{~b}-$ lower $\leq 12 \mathrm{~cm}$

Layers 2 and $3=$ previous agricultural and natural deposits

To describe the Layer 1 divisions in the order they were laid down: $1 \mathrm{~b}$ consisted of fine gray sand and fine gravel with clumps of mud; 1b-lower was lumpy, while 1bupper was laid down in fine laminae in regular fashion. Above 1b, Layer 1a consists of gray silt and very fine sand laid in a regular structure; there were tiny clumps of mud in only one trench in this layer. In Trench 1 nearest the sea, the lower stratigraphy was scoured out and large mud clumps could be seen. Ogura (2016) suggests that the mud clumps may have come from there and the rampart of the dike that borders the sea.

The thickness of Layers $1 \mathrm{a}$ and $1 \mathrm{~b}$ varied widely among the trenches, from virtually $0 \mathrm{~cm}$ to $30 \mathrm{~cm}$ thick. The thickest layers were laid east of two road ramparts, when the waves washed over the fields until they hit the road ramparts. In a third area, the thickest deposits were on the western side of a road rampart. Apparently, the waves bypassed the ramparts using a canal that then acted as a funnel to deposit more sand inland than might otherwise have occurred. 
The paddy fields were crossed by three roads and a river, all of which were accompanied by artificial earthworks. These earthworks seem to have been gutted and mixed with ocean sand for deposit farther inland. Since there were no houses or other structures present in the area, no cultural materials were found in the tsunami deposits. But given the situation with the earthworks, it could be imagined that had there been built structures seaside, it is likely their remains would have been mixed into the tsunami deposits, as were seashells from the beach.

Ogura (pers. comm. 7 December 2015) explained that the laminar sands in Layer 1a consisted of dark grains at the bottom of the layer with lighter-colored grains toward the top. The grains all tended to be the same size, but the dark grains consisted of volcanic crystals such as pyroxenes and hornblendes. He hypothesized that these crystals are volcanic erosion products that were previously deposited on the seabed, then redeposited by the tsunami waves on land.

Takaōse Site, Iwanuma City, Miyagi Prefecture - This site stretches from the third set of beach ridges into a former backmarsh and is known to have been affected by tsunami over the last five centuries (Goto 2015a:3; Kawamata 2015; Saino 2015b:249-250 and 251, Table 1). Excavations in 2013 revealed that modern paddy fields (Layer 1) had been covered by 2011 tsunami sands. Two lower sand layers are thought to be remains of earlier tsunami: Layer 4 ( $5 \mathrm{~cm}$ thick) from a tsunami caused by an earthquake in A.D. 1611 (Keichō 16 in traditional dating) and Layer 8 (20 cm thick) from the A.D. 869 (Jōgan 11) tsunami. Towada-a tephra dated to A.D. 915 were situated between these layers.

Hasunuma Site, Kujukuri-cho, Chiba Prefecture — The 2011 tsunami struck orthogonally on the Chiba coast at Kujukuri, approximately $60 \mathrm{~km}$ east of Tokyo and much farther south than is generally recognized. A survey team headed by the Geological Survey of Japan (AIST) visited the site every month for 5 months after the tsunami, establishing three transects perpendicular to the coastline and taking 29 samples for grain size analysis and running geochemical analyses (Matsumoto et al. 2016; Shinozaki et al. 2016). Tsunami deposits were a maximum of $35 \mathrm{~cm}$ thick. Several sedimentary structures and sedimentary units were identified therein. Both landward thinning of deposits and fining of grain size have previously been cited as characteristics of tsunami deposits (see Table 4). The research at the Hasunuma site confirmed that tsunami deposits tend to thin out landwards, but did not confirm that grain size becomes finer.

\section{A.D. 1771 Tsunami in the Ryukyu Islands}

Miyako Island, Okinawa Prefecture - Eight villages were established at the outlet of a small river on Miyako Island, six lined up along the coast and two behind on the river delta. All eight villages were affected by a tsunami in 1771 . They were all abandoned and three new villages were established on higher ground. At two of these new villages (Sunakawa and Tomori), rituals (napai) were created to ward off future tsunami. A stele was also erected at Maeyama on Miyako Island to commemorate the lives lost in the tsunami (Kugai 2015).

Excavations at the Tomori Motojima site revealed that the tsunami deposits covered over burials dating to the eleventh and twelfth centuries A.D. (Kugai 2015:8-9). The tsunami had also disrupted stone pavements, which had possibly been a road and had left a large coral (Portes sp.) boulder on Maibā Beach, Bora, Miyako Island. 
Ishigaki Island, Okinawa Prefecture - The same tsunami hit the southern coast of Ishigaki Island, killing over 10,000 people, or one-third of the inhabitants. Despite this, the settlements there recovered and carried on to this day as the island's main conurbation.

The maximum run-up height on Ishigaki Island was $32.7 \mathrm{~m}$ (Kugai 2015:8-9). A coral boulder named "Bari-ishi" commemorates the event. This is one of five boulders emplaced by the 1771 tsunami on the east Ishigaki coast; they were designated a Natural Monument in 2013. ${ }^{15}$ Recent excavations have revealed cracks made by earthquakes at tomb and shellmound sites which were filled with white sand containing coral - interpreted as tsunami sediments (Yamamoto 2012).

\section{A.D. 1707 Tsunami from Philippine Plate Subduction Earthquakes}

Shimizu Plain, Shizuoka Prefecture - Kitamura and Kobayashi (2014) undertook corings and a trench excavation to assess the recent tsunami deposits on the Shimizu Plain. Instead, they identified evidence of four historical earthquakes and tsunami, already known from historical documents. The team documented co-seismic uplift with the 1854 earthquake and three sand layers that may date as far back as 1498 or as recently as 1707 . They also found evidence of four prehistoric tsunami dating between 6000 and 3000 years ago in the bay sediments.

Old Kobe Foreigners' Residence Site, Kobe, Hyōgo Prefecture — Masuda and Taniguchi's (2011) urban rescue excavation at $3.5 \mathrm{~m}$ above mean sea level (AMSL) near Kobe City Hall revealed the remains of bricks from the Meiji-period Foreigners' Residence area. The site was located in the former beach lowlands just seaward of the alluvial fan of the granite Rokkō Mountains. Underneath the brick layer was $2.5 \mathrm{~m}$ of sand and clay deposits. Between 1.7 and $2.0 \mathrm{~m}$ AMSL was a $30 \mathrm{~cm}$ thick sand stratum thought to be a tsunami deposit. It was exposed in a trench more than $30 \mathrm{~m}$ long. Below this stratum extended a series of deposits $215 \mathrm{~cm}$ thick of alternating sand and mud/clay layers.

The layers in the lower stratum were formed by repeating alternating units of mud/ clay to sand, coarsening upward, with the mud/clay gradually changing to sand. The sand grains were poorly sorted, being of every size, and the larger the sand grains, the thicker the layer. This sedimentation pattern is characteristic of a floodplain, where internal lamination is poorly developed and there is a lot of mud suspended in the flood waters. This stratum is thus interpreted as a floodplain located just off the tip of the alluvial fans built by the rivers running down from the Rokkō Mountains.

One of the key factors in postulating that the upper stratum was a tsunami deposit was its completely different structure from the lower stratum. The upper stratum exhibited parallel lamination, including layers of fine-grained sand and fine gravel derived from rotten granite (masado, regolith); the gravel-sized grains were either granite pieces or feldspar crystals. The laminations are easily distinguished from the layers below. Further analysis of the upper stratum in section revealed that the grains in alternating sand layers were imbricated in different directions, indicating a change in direction of the water flow. These data are interpreted as deposits resulting from the tsunami wave reversals: first incoming and then outgoing. The upper stratum is also distinguished from normal wave deposits on a beach by its thickness. Turbulence from normal waves lasts perhaps $10 \mathrm{~s}$, while one tsunami wave can cause turbulence lasting from a few to more than $10 \mathrm{~min}$. The successions in the upper stratum indicate it was formed from three or four waves. Grain-size analysis also revealed several differences 
between the two strata. The upper stratum had consistently strong sorting for large grains $(0-2 \phi)$, but the lower stratum had more layers with finer grains $(2-4 \phi)$.

Radiocarbon dating of a piece of wood sampled from the topmost sand layer in the lower stratum gave a date of $340 \pm 20$ B.P. (redated by OxCal, the calibrated dates are A.D. 1539-1635). Three earthquakes were caused by the subduction of the Philippine Plate during or after this time: 1605, 1707, and 1854. The 1605 earthquake is thought to have been too weak to cause a tsunami, and the 1605 historical date falls within the dating range of the wood chip below the tsunami deposits. Conversely, the 1854 earthquake caused co-seismic uplift, not flooding, so the 1707 earthquake was most likely responsible for the tsunami.

Note that the tsunami layers documented in Kobe show that the Inland Sea is not immune to tsunami from earthquakes generated in the Pacific. Predictions for the next big earthquake on the Philippine Plate suggest tsunami waves could reach up to $5 \mathrm{~m}$ high in the Inland Sea area (DRI 2014).

Also note that even though the epicenter of an earthquake in 1995 was very near the Kobe shoreline, it did not cause a tsunami. Instead, tension pulled apart port facilities and plunged many sea walls and platforms into the sea. This may have been because the 1995 Kobe Earthquake was generated by an active fault, not plate subduction.

Ryūjin Lake, Kyushu — This lake, just south of Ōita City, was inundated by the 1707 Hōei tsunami accompanying the Nankai Trough earthquake in southwestern Japan. Furumura, Imai, and Maeda (2011) used numerical modeling to demonstrate that the extent of tsunami inundation required a longer source rupture distance than originally expected. Moreover, in addition to the regular Nankai Trough earthquake cycle of 100-150 years, they identified a "hyper-earthquake cycle" of every 300-500 years. Tsunami generated by hyper-earthquakes left deposits in 684, 1361, and 1707.

\section{A.D. 869 (Jögan 11) Heian-period Tsunami}

At the most general level, historical records, eyewitness observations, local traditions, and legends are important sources for identifying and describing tsunami (Goto 2015b:11; McFadgen and Goff 2007). Indeed, the usefulness of ethnographic and historical records was amply demonstrated in the search for evidence of the 1700 'orphan' tsunami, a tsunami of unknown origin that affected the northwest coast of North America. Japanese historic records revealed the source to have been a Japanese earthquake (Atwater et al. 2005). Another earthquake and tsunami were reported for May 5 Jōgan 11 (A.D. 869) in a historical document compiled in A.D. 901 entitled Nihon Sandai Jitsuroku (The true history of three periods in Japan) (Sakamoto 1991). Saino (2015b:250) cautions, however, that documentary evidence for the A.D. 869 tsunami damage at Tagajō might be exaggerated. The written record cannot be taken at face value, but must be evaluated in light of archaeological evidence. The following discussion therefore deals only with archaeological research on the A.D. 869 tsunami.

According to Saino (2012a, 2012b, 2013, 2015a:7), tsunami deposits dating to A.D. 869 have been discovered at two sites (Numamukai and Shimomasuda Iizuka) on the Sendai Plain; three others are suspected to have tsunami deposits (Fujita Shinden and Shimoiida in Sendai City and Takaōse in Iwanuma City) (Fig. 4). These are all paddy field sites that exhibit the trend of the times toward exploiting lower coastal lands, while inhabiting sites located slightly inland. Only some of the paddy fields covered by 


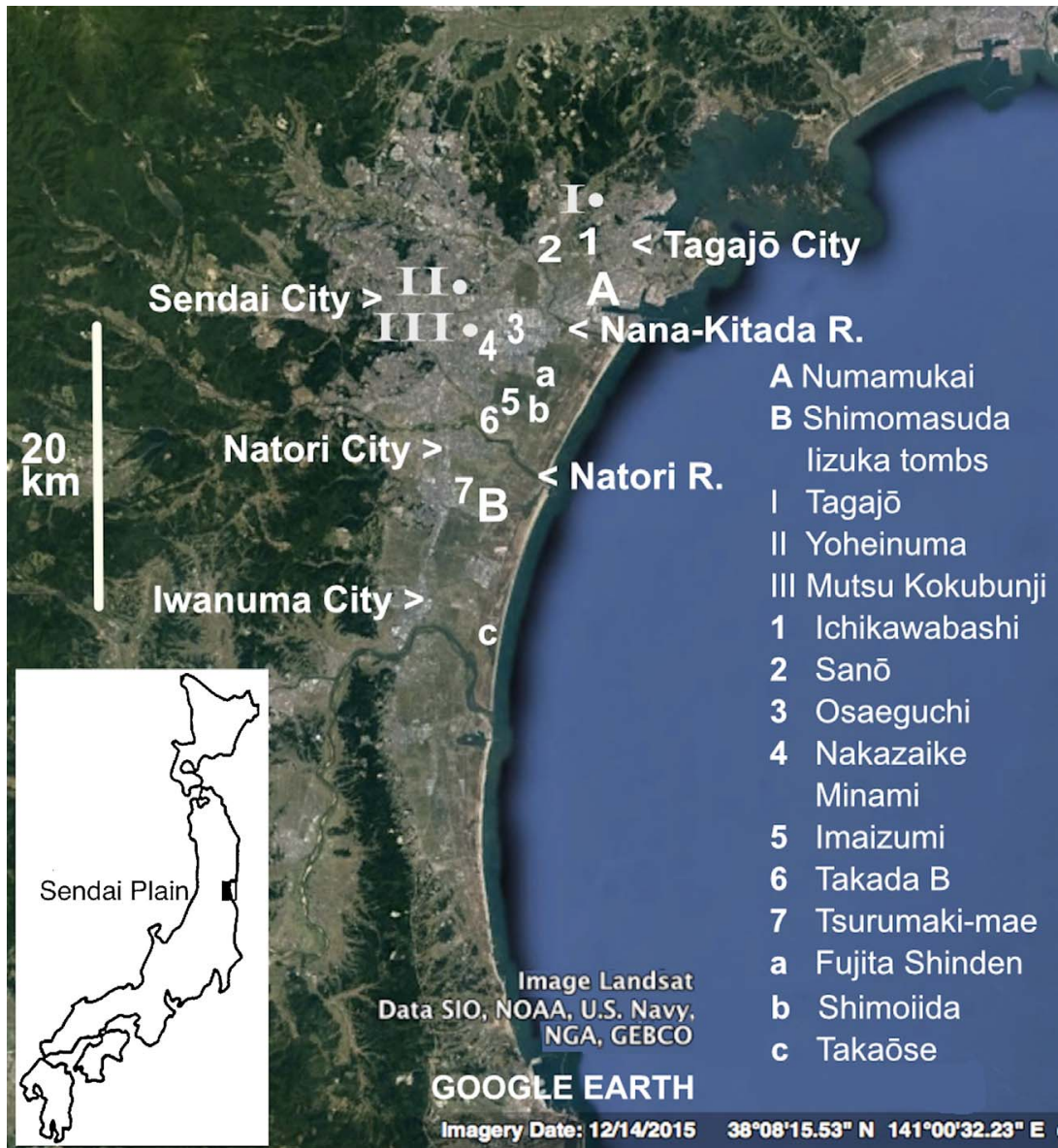

Fig. 4. Heian occupation of Sendai Plain (after Saino 2015b:252, Fig. 7). Attested tsunami remains: A, B; possible tsunami remains: a, b, c; village continuity: 1-7; important historical sites (dots): I provincial center, II - kiln site, III - provincial temple.

tsunami deposits were abandoned and seven habitation sites remained inhabited without discontinuity. This represents a great contrast to the situation in the same region during Middle Yayoi times (discussed below).

Numamukai Site, Miyagino-ku, Sendai City, Miyagi Prefecture - The Numamukai site was excavated 34 times between 1996 and 2004 (Saino 2012c, 2015a:7, 2015b:244). It extends from the beach ridge system into a prior backmarsh area. Layer $2-b$ in the beach ridge area and Layer 6 in the old backmarsh have been identified as deposits from the A.D. 869 tsunami. This archaeological evidence thus corresponds with the Nihon Sandai Jitsuroku documentation for an 869 tsunami. The sand is only about $1 \mathrm{~cm}$ thick in these areas. It is one of four natural layers sandwiched between paddy fields (Layer 9a) dating to the end of Nara/early Heian period (end of eighth century) and Towada-a tephra (Layer 4, dating to A.D. 915). No corresponding tsunami sand layers were discovered at Sanō or Ichikawabashi sites northwest of Numamukai. 
Shimomasuda Iizuka Tomb Cluster, Natori City, Miyagi Prefecture - At Shimomasuda Iizuka, Heian-period paddy field remains (Layer 7) extending more than $1000 \mathrm{~m}^{2}$ were covered with tsunami deposits (Layer 6) and thereafter abandoned (Goto 2015a; Saino $2015 b: 248$ ). The fields were dated by Towada-a tephra in Layer 4 (A.D. 915), late ninthcentury Sué ware occurring in Layer 6 of an irrigation canal, and early ninth-century Haji ware occurring in layers below Layer 6. Thus, it is proposed that these tsunami deposits were also the result of the A.D. 869 earthquake. The site was located about $1.5 \mathrm{~km}$ from the contemporaneous shoreline, so, using the 60 percent rule discussed above, the tsunami inundation distance is calculated at $2.5 \mathrm{~km}$.

\section{Middle Yayoi-period Tsunami c. 100 B.C.}

Figure 5 illustrates changing settlement patterns in the Natori River drainage, with site occupation symbols located on horizontal transects to indicate temporal trajectories. According to Saino (2015b:250-251), Yayoi sites on the Sendai Plain had been occupied from Yayoi I to IIIa phases (Fig. 5, circles); when a tsunami in Middle Yayoi IIIa inundated the rice fields with sand, many of the occupation sites were abandoned. However, some of the settlements survived into the Yayoi IIIb phase (Fig. 5, circles overlapped by lozenges) and new settlements were established farther inland (Fig. 5, lozenges). The backmarsh and beach ridge areas were not recolonized until 400 years later, during the Early Kofun period (A.D. 250-400) (Fig. 5, triangles).

From these data, it can be seen that of 27 excavated sites, 20 were occupied in Middle Yayoi (circles); 13 of the 20 were abandoned, but 6 were reoccupied in the Kofun period (circles + triangles). Two of the sites continued from Middle Yayoi into Late Yayoi and then were abandoned (circles + lozenges). Among the 27 sites, only 4 sites were occupied straight through from Middle Yayoi to Kofun (circles + lozenges + triangles), while 3 were established in new locations in Late Yayoi (independent lozenges) and 3 in Kofun (independent triangles).

Interestingly, the three sites newly established in Late Yayoi did not last into the Kofun. Two of them were in the highlands, suggesting perhaps a change in economic activities to hunting or forestry or maybe they were established for defense purposes. The other Late Yayoi settlements were positioned on the alluvial fan where dry crops might have become more important than rice growing in the narrow river flats. In any case, it is clear that settlement retreated from the beach ridges and marshlands, where fishing and rice growing were practiced. It is unknown whether this was because the villages' populations had been destroyed or whether they had retreated and not sought to return. ${ }^{16}$

Table 5 provides a closer view of the relationship of site to geography. Table 5 is divided horizontally into two river catchments, which show slightly different settlement strategies. The vertical division between Yayoi IIIa2 and IIIb marks the timing of the tsunami at 100 B.C.; another vertical division partitions the Yayoi from the Kofun period. Before the tsunami, Yayoi settlement focused on slightly elevated areas (alluvial fans and levees); after the tsunami, the Nana-Kitada River drainage was virtually abandoned, while in the Natori River drainage, settlement withdrew to the alluvial fan. Only in the Kofun period were all ecozones reoccupied, with settlement focused heavily and consistently throughout the lowlands.

Kutsukata Site, Wakabayashi-ku, Sendai City, Miyagi Prefecture - Goto (2015a:3) and Saino (2012a, 2012b, 2012c, 2012d, 2015b:244-245) report evidence for the 100 B.C. 


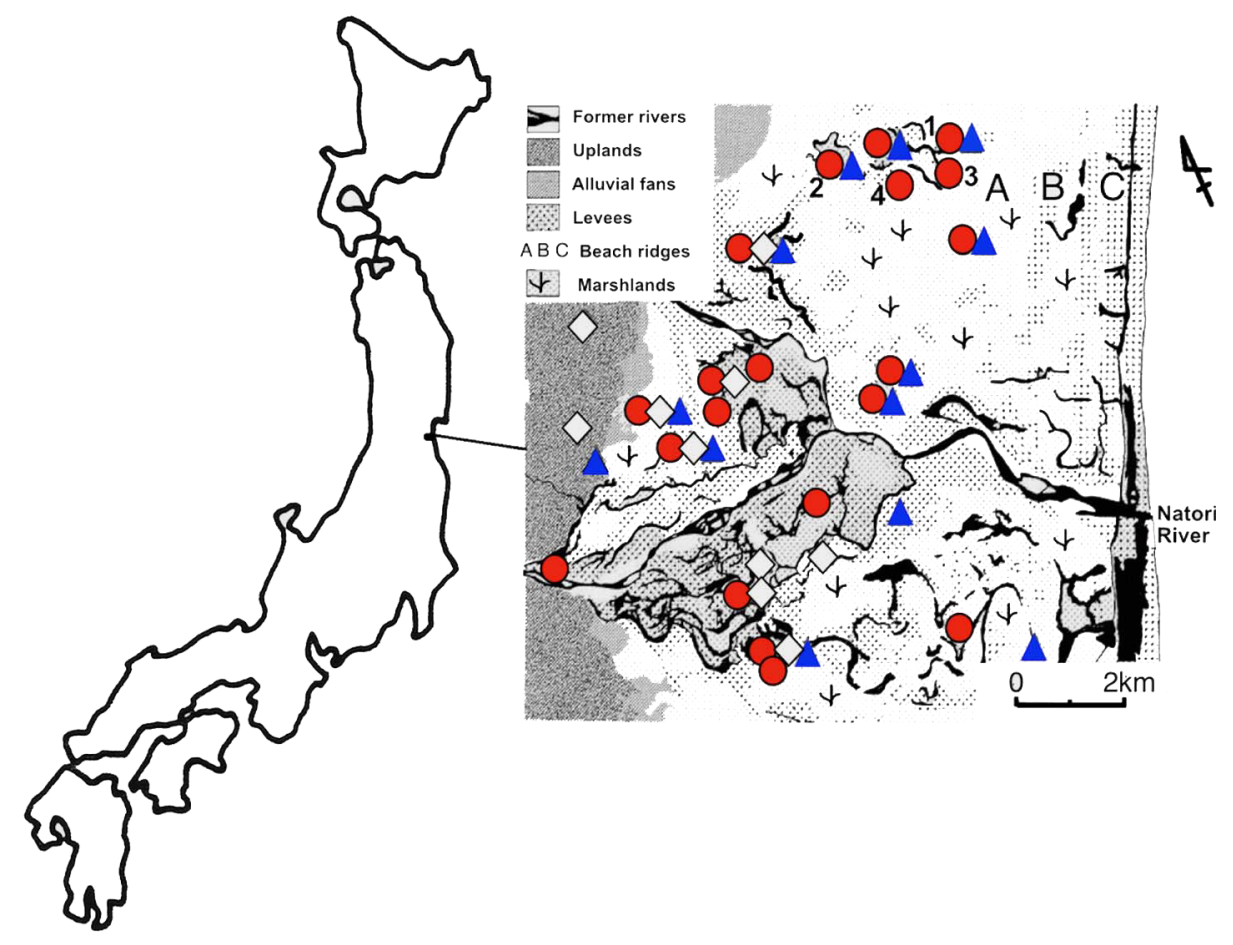

Fig. 5. Yayoi-Kofun occupation of the Natori River drainage on the Sendai Plain (after Saino 2015b:251, Fig. 6, modified with permission). Beach ridges A, B, C (from oldest to youngest) parallel the shore. Site occupation symbols are organized horizontally left to right to indicate changes through time at any one site: circles $(\bullet)$ represent Yayoi phases I-IIIa (before tsunami); lozenges $(\diamond)$ represent Yayoi IIIb-V (after tsunami); triangles $(\boldsymbol{\Delta})$ represent Early Kofun. Four of the sites discussed in detail in the text: No. 1 Kutsukata, No. 2 Nakazaike-Minami, No. 3 Arai-Hirose, and No. 4 Arai-Minami.

tsunami at the Kutsukata site (Fig. 5, No. 1). Paddy fields covering 20 ha and dating to the middle of Middle Yayoi were discovered during a 2006 excavation in the Sendai coastal lowlands. Situated $2.5 \mathrm{~km}$ from the contemporaneous shoreline, the ancient fields (Layer 6a1) were covered with a thin $(2-5 \mathrm{~cm})$ layer of sand (Layer $5 \mathrm{~b})$. The sand was similar to two samples taken from beach dunes on the coast. Grain size analysis revealed that the structure of the grain-size distribution matched the dune sand, but not the riverine flood deposits (alluvium) on the plains. All grains fell into the 'medium sand' range of $0.25-0.5 \mathrm{~mm}$, but the alluvium had a greater size range, as shown by its greater standard deviation value in Table 6 .

As seen in histogram form in Figure 6, all distributions approximated normal distribution. The alluvial flood deposits on the plain had a broad grain-size distribution (i.e., large standard deviation) (Fig. 6B), while the Layer 5b sand grains (Fig. 6A) were confined to a tight size range similar to the samples of coastal sand (Fig. 6C,D). This clearly illustrates that the sand deposited on the plain was derived from the coast and not river flooding. The sand at Layer $5 \mathrm{~b}$ of the Kutsukata site was thus traced across the plain back to the beach dunes, $0.5-1.0 \mathrm{~km}$ away. Matsumoto (2015) comments that 


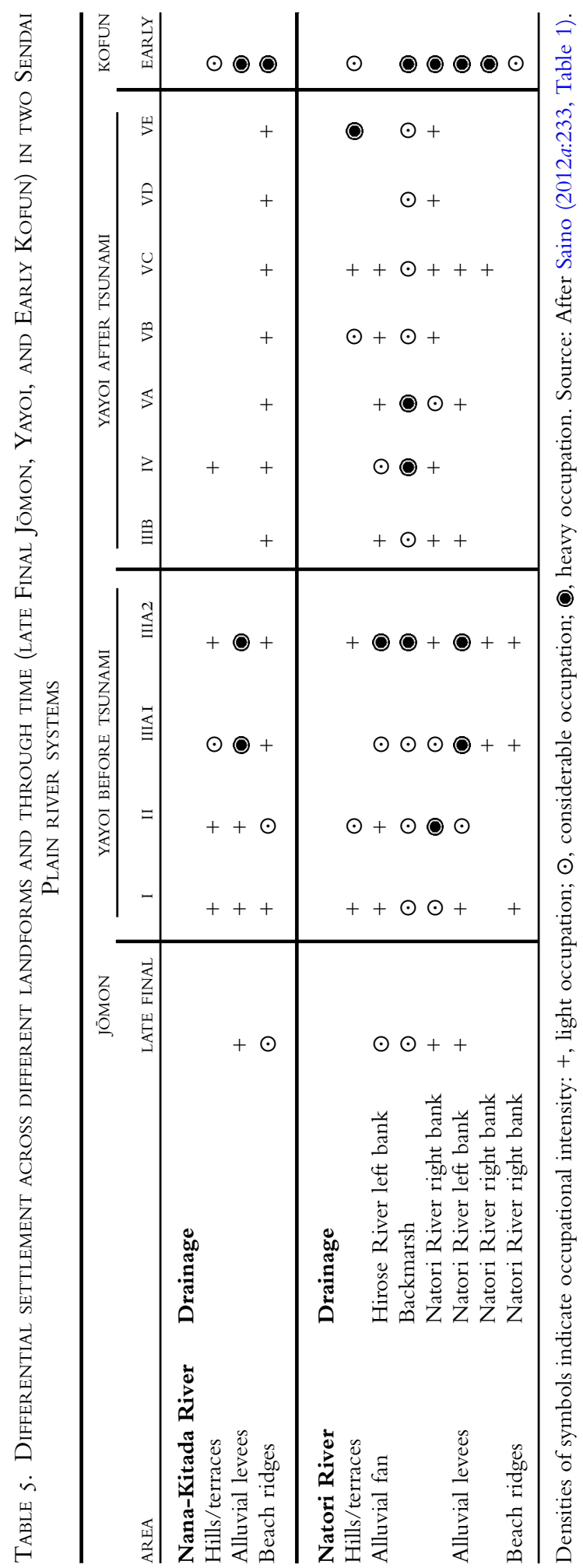


Table 6. SAND grain Sizes at Kutsukata site COMPared With DUNE SANDS AND ALlUVial SEDIMENTS

\begin{tabular}{llll}
\hline & KUTSUKATA & TWO DUNES & ALLUVIUM \\
\hline Mean $p h i(\phi)$ & 1.83 & $1.64,1.79$ & 1.92 \\
Standard deviation, $\sigma$ & 0.46 & $0.46,0.43$ & 1.19 \\
\hline
\end{tabular}

Source: Compiled from Matsumoto (2015).

sand carried across this distance could not have been carried by a storm surge. He concluded that the deposits on the paddy fields were most likely beach/dune sand that had been washed over the paddy fields by a tsunami.

Excavations of the 2011 tsunami deposits around Kutsukata can be compared with the Yayoi tsunami deposits to estimate inundation distances for the latter. The 2011 tsunami had an inundation distance of $4 \mathrm{~km}$ in this area. Based on the principle that the sand deposits ending at $2.5 \mathrm{~km}$ from the contemporaneous coastline represent 60 percent of inundation distance, the Yayoi tsunami is calculated to have had an inundation distance of more than $4.2 \mathrm{~km}$. Another comparison can be made between the relative amounts of mud in the deposits. The 2011 tsunami deposited 60-70 percent of the sand within the first $2.3 \mathrm{~km}$ or so, while $25-40$ percent of the sediments on the landward side were mud distributed over the last $2 \mathrm{~km}$ of inundation. Therefore, the 2011 tsunami deposited most of the mud at its leading edge. By contrast, the excavated Yayoi deposits were mostly sand, which suggests that the leading edge of the tsunami lay beyond the excavated area.
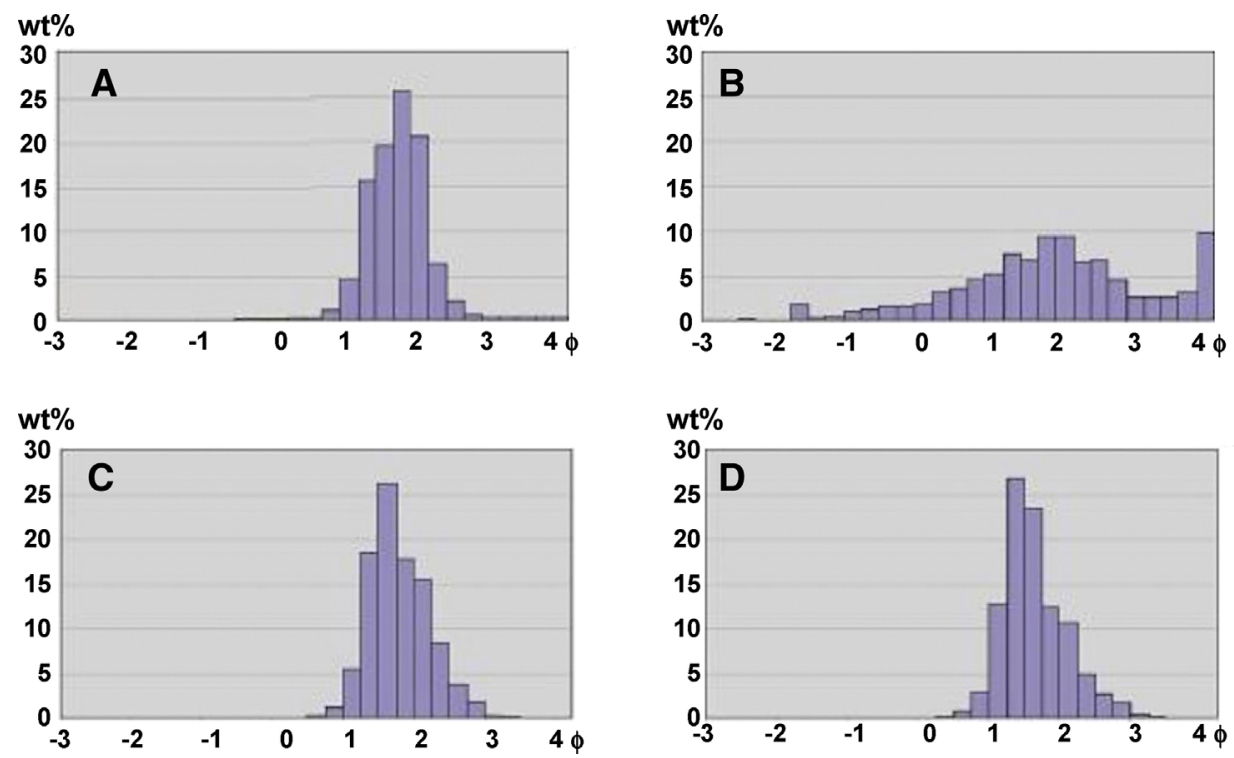

Fig. 6. Comparison of sand grain sizes (after Saino 2015b:243, Fig. 3, created by H. Matsumoto): A: sand from Layer $5 \mathrm{~b}$ at Kutsukata site; B: riverine alluvial deposits at Kutsukata site; C and D: samples of coastal sand. 
The tsunami was dated by radiocarbon from samples just above and below the sand deposit. Both came out as $2060 \pm 30$ B.P. (IAAA-62310, IAA-62311). These dates were uncalibrated in the report, but calibrating them with OxCal gives 170 B.C. to A.D. 4, which falls within the late Middle Yayoi period. Once covered by tsunami sands, the fields were abandoned; there was no evidence for recovery or reuse.

Arai-Minami, Wakabayashi-ku, Sendai City, Miyagi Prefecture - The Arai-Minami site is situated in the previous backmarsh area behind the first set of beach ridges (Fig. 5, No. 4). Paddy fields (Layer 6) covering 18 ha were excavated, revealing that tsunami sands (Layer $5 \mathrm{~b}$ ) had been deposited on them; the fields were subsequently abandoned (Saino 2015b:245-246). The tsunami deposits cover the eastern (seaward) side of the site and were supplied from that direction. These paddy and tsunami deposits are contemporaneous with those at Kutsukata site.

Arai-Hirose Site, Wakabayashi-ku, Sendai City, Miyagi Prefecture - The Arai-Hirose site (Fig. 5, No. 3) is adjacent to the Kutsukata site discussed above (Saino 2015a:6). The c. 100 B.c. earthquake caused a crack to develop in the site sediments; the crack then filled with tsunami deposits. One stone tool was discovered within the crack among the tsunami deposits.

Nakazaike-Minami Site, Wakabayashi-ku, Sendai City, Miyagi Prefecture - The Nakazaike-Minami site is situated in the previous backmarsh area of the Sendai Plain on an alluvial levee and former river course (Fig. 5, No. 2). Excavation of the site yielded mid-Middle Yayoi pottery from two river course fill episodes (Layers 14, 15) (Saino 2015b:246-248). The side of the river bank also bore two long (7-10 m) cracks caused by the c. 100 B.c. earthquake; the cracks propagated through Layer 15. Analysis of diatoms found in the fill layers revealed that marine diatoms were concentrated in Layers 15-17 downward. This area was $3.5 \mathrm{~km}$ from the contemporaneous shoreline, so the diatoms are interpreted as having been deposited during the tsunami inundation. No marine diatoms were found in Layer 14 though it contained Yayoi pottery. This suggests that the earthquake and tsunami that occurred in Layer 15 did not completely wipe out habitation in this area.

Nakasuji Site, Yamamoto-cho, Miyagi Prefecture - Nakasuji is located on a low hill spur of the Abekuma Mountains at 7-10 m elevation. This site is unusual in that paddy fields were found on higher ground, while the other sites discussed above were located in backmarsh areas. The paddy fields (Layer 6) were covered with tsunami deposits (Layers $5 b, c$ ) and thereafter abandoned (Saino 2015b:248-249). Mid-Middle-Yayoi pottery can be compared with ${ }^{14} \mathrm{C}$ dates on material just above $(2020 \pm 30$ B.P.) and below $(2070 \pm 30$ B.P. $)$ the tsunami deposits. Calibrated by IntCal 13 via OxCal 4.2, these radiocarbon dates respectively yield 107 B.C. to A.D. 59 and 174-19 B.C. dates.

\section{Middle Holocene Tsunami after Akahoya Eruption 7300 cal B.P.}

Yoko-o Site, Ōita City, Ōita Prefecture - Evidence of tsunami sediments has been found at the Yoko-o Shellmound site in Ōita City, Ōita Prefecture, Kyushu (Fujiwara et al. 2010). This tsunami is assigned to the eruption of the Kikai-Akahoya (K-Ah) tephra from the Kikai caldera off the tip of southern Kyushu, which covered the southern tip of the island (Fujiwara et al. 2010; Maeno and Imamura 2007; Maeno et al. 2006). 


\section{CONCLUSIONS}

Tsunami archaeology is just in its beginning stages. Cooperation is required amongst archaeologists and geologists to identify tsunami deposits in archaeological sites and off-site localities. Great strides have been made in differentiating tsunami deposits from storm deposits, with a wide variety of geochemical, sedimentary, and distributional evidence being taken into account. The recognition of tsunami sands and gravels in conjunction with cultural materials at archaeological sites aids geological dating of tsunami cycles.

While this first phase of intensive geological work on identification is being conducted, archaeologists are beginning to assess the impacts on habitable areas and resources, with the aim of understanding human responses to tsunami through time. In Japan, the Sendai Plain is the locus of the most advanced investigations. Considerable differences are noted there among peoples of different prehistoric and historic periods. While abandonment was apparent during the Middle Yayoi and presumably for as yet undocumented earlier periods, later historic occupants and modern peoples seem to have been able to overcome the devastation from tsunami and recover their fields to grow crops. When fields could not be recovered or resources were too depleted, tsunami survivors have moved their settlements or pursued different economic activities.

Researchers following Shimoyama's (2002a) parameters for investigating disasters in the archaeological record are still struggling to identify tsunami deposits and the causes of tsunami among multiple possibilities (i.e., earthquakes, landslides, volcanoes). Such research supplies data about Shimoyama's first two parameters, initiation and immediate causes. For archaeological sites where tsunami deposits have been confirmed, the limited areal extent of excavation confines observations to the stratigraphic sequence and precludes wider understanding of the extent of damage and human reactions. In order to address Shimoyama's last parameter (reactions to tsunami), a regional approach such as Saino's, which can track population movements and subsistence changes, is necessary.

For an intimate view of reactions to tsunami, it would be instructive to assess the lifestyles of people who occupied those sites on the Sendai Plain that survived through the tsunami or were established afterwards (Fig. 5). Did they show a change in organization or subsistence economies? Can migrants be traced within the region or beyond? What happened to village sizes and structure? Did inhabitants stop growing rice in the lowlands and turn to fishing and hunting in the uplands? These questions go beyond the identification and documentation of tsunami strata and excavation of destroyed settlements. Future research will certainly illuminate reactions of previous inhabitants to the constant but unpredictable threat of tsunami along the "hostile shores" of the Japanese archipelago, using McFadgen's (2007) phrase.

Being limited to coastal fringes, tsunami damage seldom leads to collapse of a society or civilization, though the socio-economic status of the affected society is crucial to the nature of human response. A massive tsunami attacking Tokyo directly would be extremely destructive. Whether or not tsunami can be considered an agent forcing cultural change (Force 2015; Goff and Nunn 2016) or an "event" in Sewell's (2005) terms, archaeology as a discipline has moved beyond merely rejecting environmental determinism to really considering the effects of environmental changes on society. Disaster archaeology, including tsunami archaeology, is thus a timely and welcome approach to understanding the situation of the world today. 


\section{ACKNOWLEDGMENTS}

I am indebted to Eric Force and Susanna Hoffman for inviting me to participate in a panel on human reactions to tsunami at the Society for Applied Anthropology meetings, 28 March-2 April 2016 in Vancouver, BC. This paper was written in conjunction with my presentation and received valued comments from my fellow panelists. The paper's preparation was conducted in Japan under the auspices of Kyushu University's 世界トッ プレベル研究者招へいプログラム Sekai toppu-reberu kenkyūsha shōhei puroguramu, Progress 100 [Program to invite World Top-Level Researchers, Progress 100] while affiliated with the Department of Japanese History \& History of Ideas, Graduate School of Humanities and hosted by Prof. Ellen van Goethem from 12 October 2015 to 31 January 2016. Interviews with Ogura Tetsuya 小倉徹也 of the Osaka City Cultural Properties Association, Nakajō Takeshi 中城武司 at the Osaka Museum of Natural History, and Saino Hirohiko 斎野裕彦 at the Sendai City Cultural Properties Section gave me personal insights into the problems facing both geologists and archaeologists researching tsunami deposits. I thank them all deeply, and Saino-san especially for assistance with the illustrations. I am greatly indebted to the Earth Science Department of Durham University for sponsoring my research via remote library access, without which this research could not have been done.

\section{NOTES}

1. Of course, the Fukushima nuclear disaster adds an extra dimension to the 2011 event that was absent in prior times.

2. For a graphic comparison, see the Tsunami! website, maintained by the Department of Earth and Space Sciences, College of the Environment, University of Washington. URL: earthweb.ess.washington. edu/tsunami/.

3. This is three times older than Mesoamerican and South American records and far longer ago than records from Kuril/Kamchatka, North America and Hawai'i, or New Zealand/Polynesia (Goto $2015 b: 10)$.

4. For descriptions of the archaeological periods of Japan, see Barnes (2015b).

5. PTWS is accessed on the International Tsunami Information Center (ITIC) website, URL: itic.iocunesco.org $/$ index.php?option=com_content\&view $=$ category\&id=1153\&Itemid=1153.

6. The Tsunami Laboratory website is maintained by the Institute of Computational Mathematics and Mathematical Geophysics in Novosibirsk, Russia, URL: tsun.sscc.ru/tsun_hp.htm. The National Geophysical Data Center (NGDC) is now known as the NOAA (National Oceanic and Atmospheric Administration) National Centers for Environmental Information; the website can be accessed at URL: www.ngdc.noaa.gov/.

7. "Integrated Tsunami Database for the World Ocean (WinITDB/WLD)" can be accessed from the Tsunami Laboratory website, URL: tsun.sscc.ru/WinITDB.htm.

8. Access the "List of tsunamis" on the International Tsunami Information Center website, URL: itic.iocunesco.org/index.php.

9. The "NGDC/WDS Global Historical Tsunami Database, 2100 B.c." can be accessed on the NOAA National Centers for Environmental Information website, URL: www.ngdc.noaa.gov/hazard/tsu_db. shtml.

10. Map titled "Global Tsunami Sources 1650 B.c. to A.D. 2008 from Earthquake, Volcano, Landslide, and Other Causes," available from URL: itic.ioc-unesco.org/images/docs/posteroct08_small.jpg.

11. The "Japan Tsunami Trace database" can be accessed at URL: tsunami-db.irides.tohoku.ac.jp/ tsunami/mainframe.php, with the March 2016 Tsunami Trace Database Operation Manual 7.2 Edition available for download at URL: tsunami-db.irides.tohoku.ac.jp/tsunami/manual_ippanEN.pdf.

12. The fact that boulders can be imbricated by strong tsunami waves provides a piece of evidence for a Bristol Channel tsunami in 1607 (Roberts 2005).

13. For an intimate visualization, see the BBC documentary about a possible tsunami in the Bristol Channel in 1607 (Roberts 2005).

14. This list is constantly being updated. It was expanded to 21 proxies in Chagué-Goff et al. (2011).

15. Listed in Cultural Heritage Online website, URL: bunka.nii.ac.jp/heritages/detail/240625.

16. The situation of the 1998 tsunami in Papua New Guinea is a modern comparator for what might have happened to lowland settlements in Japan (Davies 2002). 


\section{REFERENCES CITED}

ARAI, FUSAO, ED.

1993 Kazanbai Kōkogaku 火山灰考古学 [Volcanic Ash Archaeology]. Tokyo: Kokon Shoin.

Athukorala, Prema-chandra, and Budy P. Resosudarmo

2005 The Indian Ocean tsunami: Economic impact, disaster management and lessons. Asian Economic Papers 4(1):1-39.

Atwater, Brian F., Satoko Musumi-Rokkaku, Kenji Satake, Yoshinobu Tsuji, Kazue Ueda, and David

K. YAMAGUCHI

2005 The Orphan Tsunami of 1700: Japanese Clues to a Parent Earthquake in North America. Reston, VA: USGS and University of Washington Press.

BARnes, Gina L.

2010 Earthquake archaeology in Japan: An overview, in Ancient Earthquakes: 81-96, ed. M. Sintubin, I. S. Stewart, T. M. Niemi, and E. Altunel. Boulder, CO: Geological Society of America.

2015a Vulnerable Japan: The tectonic setting of life in the archipelago, in Environment and Society in the Japanese Islands: From Prehistory to the Present: 21-42, ed. B. L. Batton and P. C. Brown. Corvallis, OR: Oregon State University Press.

$2015 b$ Archaeology of East Asia: The Rise of Civilization in China, Korea, and Japan, $3^{\text {rd }}$ ed. Oxford: Oxbow Books.

Cartwright, Julyan H.E., and Hisami Nakamura

2008 Tsunami: A history of the term and of scientific understanding of the phenomenon in Japanese and Western culture. Notes and Records of the Royal Society 62:151-166.

Chagué-Goff, Catherine, Anita Andrew, Witold Szczuciński, James Goff, and Yuichi Nishimura

2012 Geochemical signatures up to the maximum inundation of the 2011 Tohoku-oki tsunami: Implications for the 869 A.D. Jōgan and other palaeotsunamis. Sedimentary Geology 282:65-77.

Chagué-Goff, Catherine, Jean-Luc Schneider, James R. Goff, Dale Dominey-Howes, and Luke STROTZ

2011 Expanding the proxy toolkit to help identify past events: Lessons from the 2004 Indian Ocean Tsunami and the 2009 South Pacific Tsunami. Earth Science Reviews 107(1-2):107-122.

Costa, Pedro J. M., Cesar Andrade, Cascalho João, Alastair G. Dawson, Maria C. Freitas, Raphael Paris, and Sue Dawson

2015 Onshore tsunami sediment transport mechanisms inferred from heavy mineral assemblages. The Holocene 25(5):795-809.

COX, DOAK

2001 The inappropriate tsunami icon. Science of Tsunami Hazards 19(2):87-92.

DAvies, Hugh

2002 Tsunamis and the coastal communities of Papua New Guinea, in Natural Disasters and Cultural Change: 28-42, ed. R. Torrence and J. Grattan. London: Routledge.

DiAMOND, JARED

2011 Collapse: How Societies Choose to Fail or Succeed. London: Penguin.

Dominey-Howes, T. M. Dale, Geoff S. Humphreys, and Paul P. Hesse

2006 Tsunami and palaeotsunami depositional signatures and their potential value in understanding the late-Holocene tsunami record. The Holocene 16(8):1095-1107.

DOUGHTON, SANDi

2005 Signs' tsunami icon misleads. The Seattle Times (online) 17 January 2005. URL: www. seattletimes.com/seattle-news/signs-tsunami-icon-misleads/.

DRi [Disaster Reduction and Human Renovation Institution]

2014 1.17 Hanshin-Awaji Great Earthquake after 20 years: Messages to the future, to the world, an exhibit at The Great Hanshin-Awaji Earthquake Memorial, Kobe, 17 January 2014-28 June 2015.

Dunbar, Paula, Marie Eblé, George Mungov, Heather McCullough, and Erica Harris

2013 NOAA's historical tsunami event database, raw and processed water level data, and model output relevant to the 11 March 2011 Tohoku, Japan earthquake and tsunami, in Tsunami Events and Lessons Learned: Environmental and Societal Significance: 113-127, ed. Y. A. Kontar, V. Santiago-Fandìno, and T. Takahashi. Advances in Natural and Technological Hazards Research 35. Dordrecht, Netherlands: Springer. 
FACKLER, MARTIN

2011 Tsunami warnings, written in stone. The New York Times 20 April 2011. URL: www.nytimes. com/2011/04/21/world/asia/21stones.html?_r=2.

Fine, Isaac V., Evgueni A. Kulikov, and Josef Y. Cherniawsky

2013 Japan's 2011 tsunami: Characteristics of wave propagation from observations and numerical modelling. Pure and Applied Geophysics 170(6):1295-1307.

ForCe, ERIC

2015 Impact of Tectonic Activity on Ancient Civilizations. Lanham: Lexington Books.

Fritz, Hermann M., Fahad Mohammed, and Jeseon Yoo

2009 Lituya bay landslide impact generated mega-tsunami 50th anniversary. Pure and Applied Geophysics 166(1-2):153-175.

FuJIWARA OSAMU 藤原 治

2015 Tsunami taisekibutsu no kagaku 津波堆積物の科学 [The Science of Tsunami Deposits]. Tokyo: Tokyo University Press.

Fujiwara OSAmu 藤原治, Machida Hiroshi 町田 洋, AND SHIOCHI Jun'ICHi 塩地潤一

2010 大分市横尾貝塚に見られるアカホヤ噴火に伴う津波堆積物 Oita-shi Yoko-o Kaizuka ni mirareru Akahoya funka ni tomonau tsunami taisekibutsu [Tsunami sediments accompanying the Akahoya eruption seen at the Yoko-o Shellmound site in Oita City]. 第四紀研究 Daiyonki Kenkyū 49:23-33.

Fukasawa, Yuriko

2015 Ainu oral tradition about tsunami, in Symposium: Traces and Experiences of Past Tsunami Disasters in the Pacific Rim, and the Succession of Knowledge, 14 March 2015, Sendai: 16, ed. Cultural Properties Section and Sendai City Board of Education. Sendai: Sendai-shi Kyōi (in Japanese and English).

Furumura, Takashi, Kentaro Imai, and Takuto Maeda

2011 A revised tsunami source model for the 1707 Hoei earthquake and simulation of tsunami inundation of Ryujin Lake, Kyushu, Japan. Journal of Geophysical Research 116:B02308.

Gavin, Daniel G.

2001 Estimation of inbuilt age in radiocarbon ages of soil charcoal for fire history studies. Radiocarbon 43(1):27-44.

Gilhooly, Robert

2012 Islands on land could make towns tsunami-proof. New Scientist 2852 (15 February 2012). Available at URL: www.newscientist.com/article/mg21328525-800-islands-on-land-couldmake-towns-tsunami-proof/.

GLickson, ANDrew Y.

2004 Early Precambrian asteroid impact-trigger tsunami: Excavated seabed, debris flows, exotic boulders, and turbulence features associated with 3.47-2.47 Ga-old asteroid impact fallout units, Pilbara Craton, Western Australia. Astrobiology 4(1):19-50.

Goff, J., C. Chagué-Goff, And S. Nichol

2001 Palaeotsunami deposits: A New Zealand perspective. Sedimentary Geology 143(1-2):1-6.

Goff, James R., Catherine Chagué-Goff, and James P. Terry

2012 The value of a Pacific-wide tsunami database to risk reduction: Putting theory into practice. Geological Society, London, Special Publications 361:209-220.

Goff, James R., and Bruce G. McFadgen

2001 Catastrophic seismic-related events and impact on prehistoric human occupation, coastal New Zealand. Antiquity 75(287):155-162.

2003 Large earthquakes and the abandonment of prehistoric coastal settlements in 15th Century New Zealand. Geoarchaeology 18(6):609-623.

Goff, James, And Patrick D. NunN

2016 Rapid societal change as a proxy for regional environmental forcing: Evidence and explanations for Pacific island societies in the 14-15th centuries. Island Arc 25(5):305-315.

Goto, Kazuhisa

2015a Mechanisms of near- and far-field tsunamis, in Symposium: Traces and Experiences of Past Tsunami Disasters in the Pacific Rim, and the Succession of Knowledge, 14 March 2015, Sendai: 2-3, ed. Cultural Properties Section and Sendai City Board of Education. Sendai: Sendai-shi Kyōi (in Japanese and English). 
$2015 b$ Tsunami evidence in the Pacific, in Symposium: Traces and Experiences of Past Tsunami Disasters in the Pacific Rim, and the Succession of Knowledge, 14 March 2015, Sendai: 10-13, ed. Cultural Properties Section and Sendai City Board of Education. Sendai: Sendai-shi Kyōi (in Japanese and English).

Goto, Kazuhisa, Catherine Chagué-Goff, Shigehiro Fujino, James Goff, Bruce Jaffe, Yuichi Nishimura, Bruce Richmond, Daisuke Sugawara, Witold Szczuciński, David R. Tappin, Robert C. Witter, And Eko Yulianto

2011 New insights of tsunami hazard from the 2011 Tohoku-oki event. Marine Geology 290 $(1-4): 46-50$.

Goto, Kazuhisa, Shigehiro Fujino, Daisuke Sugawara, and Yuichi Nishimura

2014 The current situation of tsunami geology under new policies for disaster countermeasures in Japan. Episodes 37(4):258-264.

Goto, Tomoko, Kenji Satake, Toshihiko Sugai, Takeo Ishibe, Tomoya Harada, and Satoko Murotani 2015 Historical tsunami and storm deposits during the last five centuries on the Sanriku coast, Japan. Marine Geology 367(September):105-117.

GOULD, RiCHARD

2007 Disaster Archaeology. Salt Lake City, UT: University of Utah Press.

Guttenfelder, David, and Eugene Hoshiko

2016 Cities flattened by Japan tsunami literally rise. AP Images Spotlight (blog) 9 March 2016. URL: apimagesblog.com/blog/2016/03/09/cities-flattened-by-japan-tsunami-literally-rise.

Hamasaki, Shinji, Yūko Okazaki, Shōichi Shimoyama, Toshihiko Ichihara, and Kimihiko Ōki

2012 Evidence of tsunami and high tides at Kajikurihama site, Shimonoseki City, Yamaguchi Prefecture. Kōkogaku Kenkyū 59(2):1-5.

IGARASHI, YoSUKE

2007 Abstract: Verification of Japanese tsunami data in the Integrated Tsunami Database (ITDB). Tsunami Commission Workshop 2007. URL: www.research.jisao.washington.edu/tsunamicom mission/workshop2007/ABSTRACT_ALL.pdf.

IMAMURA, FUMIHIKO

n.d. Recent tsunami research in Japan. PPT presentation. URL: www.fzk.uni-hannover.de/ fileadmin/institut/Veranstaltungen/DFG-RT/DFG-pdf/2.1.1_imamura.pdf.

ISHIBASHI, HIDEAKI

2015 Tsunami survivors open new town on Miyagi farmland. Asahi Shimbun 20 July 2015. URL: http://www.fukushima-is-still-news.com/2015/07/new-town-in-miyagi-pref.html.

Iwabuchi, Yoko, Hideharu Sugino, Fumihiko Imamura, Yoshinobu Tsuji, Yuya Matsuoka, Kentaro Imai, and Nobuo Shuto

2012 Development of tsunami trace database with reliability evaluation on Japan coasts. Doboku Gakkai Ronbunshū B2 (Kaigan Kōgaku) [Journal of Japan Society of Civil Engineers, Ser. B2 (Coastal Engineering)] 68(2):I_1326-I_1330 (in Japanese with English title and abstract).

Jaffe, Bruce, Bruce Richmond, and Helen Gibbons

2011 International team studies tsunami deposits in Japan to improve understanding and mitigation of tsunami hazards. Sound Waves (June). URL: soundwaves.usgs.gov/2011/06/.

Joseph, ANTONy

2011 Tsunamis: Detection, Monitoring, and Early-Warning Technologies. Burlington, MA: Academic Press.

KANER, SiMON

2011 Tidal wave: The day Japan shook. Current World Archaeology 49:22-24.

Kaner, Simon, Junko Habu, and Akira Matsui

2011 Rescuing archaeology affected by the Japanese earthquake and tsunami. Antiquity 85. URL: www.antiquity.ac.uk/projgall/kaner329/.

KAWAMATA, TAKAHISA

2015 Takaōse site, Iwanuma City, Miyagi Prefecture Heian-Edo periods (ninth to first half of the seventeenth centuries). Noteworthy Archaeological Sites (website). URL: archaeology.jp/sites/ 2015/takaose.htm.

KEYS, DAVID

1999 Catastrophe: An Investigation in the Origins of the Modern World. London: Century. 
Kitamura, Akihisa, and Konatsu Kobayashi

2014 Geologic evidence for prehistoric tsunamis and coseismic uplift during the A.D. 1854 AnseiTokai earthquake in Holocene sediments on the Shimizu Plain, central Japan. The Holocene 24 (7):814-827.

Kugai, Mitsugu

2015 The tsunami trace and disaster in Miyako and Yayaema Islands, in Symposium: Traces and Experiences of Past Tsunami Disasters in the Pacific Rim, and the Succession of Knowledge, 14 March 2015, Sendai: 8-9, ed. Cultural Properties Section and Sendai City Board of Education. Sendai: Sendai-shi Kyōi (in Japanese and English).

Lockridge, Patricia A.

1990 Nonseismic phenomena in the generation and augmentation of tsunamis. Natural Hazards and Earth System Sciences 3:403-412.

Maeno, Fukashi, and Fuminiko Imamura

2007 Numerical investigations of tsunamis generated by pyroclastic flows from the Kikai caldera, Japan. Geophysical Research Letters 34:L23303.

Maeno, Fukashi, Fuminiko Imamura, and Hiromitsu Taniguchi

2006 Numerical simulation of tsunamis generated by caldera collapse during the 7.3 ka Kikai eruption, Kyushu, Japan. Earth, Planets and Space 58:1013-1024.

MASUdA FujIO 増田富士雄 AND TANIGUCHI KeISUKE 谷口圭輔

2011 旧神戸外国人居留地遺跡で観察された江戸時代の振動流 (津波?) 堆積物 Kyū Kōbe gaikokujin kyoryūchi iseki de kansatsu sareta Edo jidai no shindōryū (tsunami?) taisekibutsu [Edo-period turbulence (tsunami?) sediments investigated at the Old Kobe Foreigners' Residence site], in 旧神戸外国人居留地遺跡発掘調査報告 Kyū Kōbe gaikokujin kyoryūchi iseki hakkutsu chōsa hōkoku [Old Kobe Foreigners' Residence Site: Excavation Report]: 9-15. Kobe: Kobe Kyōi 神戸教委 [Kobe City Board of Education].

Matsumoto, Dan, Yuki Sawai, Koichiro Tanigawa, Osamu Fujiwara, Yuichi Namegaya, Masanobu Shishikura, Kyoko Kagohara, and Haruo Kimura

2016 Tsunami deposit associated with the 2011 Tohoku-oki tsunami in the Hasunuma site of the Kujukuri coastal plain, Japan. Island Arc 25(5):369-385.

Matsumoto, Hideaki

2015 Characteristics of tsunami deposit about 2000 years ago and some geological sections of tsunami deposit A.D. 869 in the Sendai Plain, in Symposium: Traces and Experiences of Past Tsunami Disasters in the Pacific Rim, and the Succession of Knowledge, 14 March 2015, Sendai: 4-5, ed. Cultural Properties Section and Sendai City Board of Education. Sendai: Sendai-shi Kyōi (in Japanese and English).

McFadgen, Bruce G.

1982 Dating New Zealand archaeology by radiocarbon. New Zealand Journal of Science 25:379-392.

2007 Hostile Shores: Catastrophic Events in Prehistoric New Zealand and their Impact on Maori Coastal Communities. Auckland: Auckland University Press.

McFadgen, B. G., And J. R. Goff

2007 Tsunamis in the New Zealand archaeological record. Sedimentary Geology 200(3-4):263-274.

Minoura, K., F. Imamura, D. Sugawara, Y. Kono, and T. Iwashita

2001 The 869 Jōgan tsunami deposit and recurrence interval of large-scale tsunami on the Pacific coast of northeast Japan. Journal of Natural Disaster Science 23(2):83-88.

MiYAmoto, KuniaKi

2010 Numerical simulation of landslide movement and Unzen-Mayuyama disaster in 1792, Japan. Journal of Disaster Research 5(3):280-287.

Morton, Robert A., Guy Gelfenbaum, and Bruce E. Jaffe

2007 Physical criteria for distinguishing sandy tsunami and storm deposits using modern examples. Sedimentary Geology 200(3-4):184-207.

Morton, Robert A., Guy Gelfenbaum, Bruce E. Jaffe, and Helen Gibbons

2007 Distinguishing tsunami from storm deposits in the geologic record. Sound Waves (November). URL: soundwaves.usgs.gov/2007/11/. 
NOAA (National Oceanic and Atmospheric Administration)

2015 Great Tohoku, Japan earthquake and tsunami, 11 March 2011 (webpage), on NOAA National Centers of Environmental Information website, available at URL: www.ngdc.noaa.gov/hazard/ 11 mar2011.html.

Obermeier, Stephen F.

1996 Using liquefaction-induced features for paleoseismic analysis, in Paleoseismology: 331-396, ed. J. P. McCalpin. San Diego, CA: Academic Press.

OGura TETSUyA 小倉徹也

2016 福島県南杣市小高川下流域における 3.11 津波堆積物の堆積状況 Fukushima-ken Minami-Sōma-shi Odakagawa karyūiki ni okeru 3.11 tsunami taisekibutsu no taiseki jōkyō [The conditions of deposit of the March 11th tsunami sediments in the lower drainage of Odaka River, Minami Sōma City, Fukushima Prefecture]. Ōsaka Bunkazai Kenkyūsho Kiȳo 大阪文化財研究所紀要 2016(March):1-12.

OKamura, Katsuyuki

2015 Tsunami and heritage after the 2011 Great East Japan Earthquake, in Water and Heritage: Material, Conceptual and Spiritual Connections: 245-256, ed. William J. H. Willems and Henk P. J. van Schaik. Leiden: Sidestone Press.

Okamura, Katsuyuki, Atsushi Fujisawa, Yasuhisa Kondo, Yu Fujimoto, Tomokatsu Uozu, Yumiko Ogawa, Simon Kaner, and Koji Mizoguchi

2013 The Great East Japan Earthquake and cultural heritage: Towards an archaeology of disaster. Antiquity 87(335):258-269.

Pendick, DANIEL

1998 Remembrance of Waves Past (sidebar), Waves of Destruction: Tsunamis (program), in Savage Earth (series), PBS Online (website). URL: www.pbs.org/wnet/savageearth/tsunami/html/ sidebar2.html.

ROBERTS, SAM (DIRECTOR)

2005 “The killer wave of 1607,” BBC Timewatch, season 24, episode 5 (1 April 2005). URL: www. bbc.co.uk/iplayer/episode/b0078w1y/timewatch-20042005-the-killer-wave-of-1607.

SAINO Hirohiko 斎野裕彦

2012a Sendai heiya chūhokubu ni okeru Yayoi jidai, Heian jidai no tsunami konseki to shūraku dōtai 仙台平野中北部における弥生時代・平安時代の津波痕跡と集落動態 [Trends in settlement change and tsunami deposits of the Yayoi and Heian periods in the central northern part of Sendai plain]. 平成19年度 平成23年度文部科学省私立大学学術高度化推進事業 「オープン・リサーチ・センター整備事業」東北地方における環境・生業・技術 に関する歴史動態的総合研究 研究成果報告書 Heisei 19 nendo 〜 Heisei 23 nendo MonbuKagakusho shiritsu daigaku gakujutsu kōdoka suishin jigyō 'open research center seibi jigyo'?:

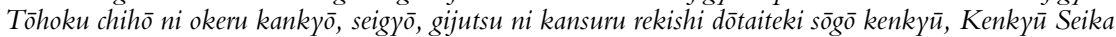
Hōkokusho [Heisei years 19-23 MonbuKagakusho's project drive to increase private universities' academic level via 'the open research center development project': Coordinated research on historical trends in environment, industry and skills in the Tohoku region research results report] vol. 1: 225-258.

$2012 b$ Sendai heiya no nōkō saigai konseki: Yayoi kara Kinsei e 仙台平野の農耕災害痕跡弥生か ら近世へ [Evidence of agricultural disasters on the Sendai Plain: From Yayoi to Pre-modern periods], in Kōza Tōhoku no Rekishi 4: Saigai to Kankyō 講座東北の歴史4: 災害と環境 [Collected writings on Tōhoku history, vol. 4: Disaster, environment]: 186-215. Tokyo: Seibundō-Shinkōsha.

2012c Kutsukata site and Numamukai site in Sendai City. Kōkogaku Kenkyū 58(4):114-115.

2012d Excavated evidence of tsunami in Sendai plain. Kōkogaku Kenkȳ 58(4):6-11.

2013 Jōgan jūichinen Mutsunokuni shinsai kiji to shizen saigai konseki kenkyū 貞観十一年陸奥国 震災記事と自然災害痕跡研究 [Natural disaster evidence research and ancient documents on the Jōgan 11 earthquake in Mutsunokuni], in 市史仙台 Shishi Sendai [Sendai City History]: 4-21, ed. 仙台市立博物館 [Sendai City Museum]. Miyagi: Sendai Kyōi 仙台市教委.

$2015 a$ Tsunami disasters of Yayoi period and Heian period in the Sendai Plain, in Symposium: Traces and Experiences of Past Tsunami Disasters in the Pacific Rim, and the Succession of Knowledge, 14 March 2015, Sendai: 6-7, ed. Cultural Properties Section and Sendai City Board of Education. Sendai: Sendai-shi Kyōi (in Japanese and English).

2015 b Sendai heiya no iseki ni nokosareta tsunami konseki 仙台平野の遺跡に残された津波痕跡 [Tsunami evidence left in archaeological sites on the Sendai Plain], in Iwanuma Shishi 岩沼市史 [Iwanuma City History] vol. 4: 240-254, ed. Iwanuma-shi Kyōiku Iinkai 岩沼市教育委員会 [Iwanuma City Board of Education]. Miyagi: Iwanuma-shi Kyōi 岩沼市教委. 
SAKAMOTO, TARŌ

1991 The Six National Histories of Japan, trans. John S. Brownlee. Vancouver and Tokyo: UBC Press and University of Tokyo Press.

SANGAWA, AKIRA

1988 Kōkogaku no kenkyū taishō ni mitomerareru jishin no konseki 考古学の研究対象に認めら れる地震の痕跡 [Traces of earthquakes recognizable in archaeological features]. Kodaigaku Kenkyū 古代学研究 116:1-16.

SATAKE, K.

2007 Tsunamis, in Treatise on Geophysics, v. 4: Earthquake Seismology: 484-510, ed. H. Kanamori. Amsterdam: Elsevier.

SATO, SHINJI

2015 Characteristics of the 2011 Tohoku tsunami and introduction of two level tsunamis for tsunami disaster mitigation. Proceedings of the Japan Academy Series B 91(6):262-272.

Sawai, Yuki, Yushiro Fuji, Osamu Fujiwara, Takanobu Kamataki, Junko Komatsubara, Yukinobu Okamura, Kenji Satake, and Masanobu Shishikura

2008 Marine incursions of the past 1500 years and evidence of tsunamis at Suijin-numa, a coastal lake facing the Japan Trench. The Holocene 18(4):517-528.

Scheffers, A., AND D. Kelletat

2003 Sedimentologic and geomorphologic tsunami imprints worldwide - a review. Earth-Science Reviews 63(1-2):83-92.

Schlanger, Nathan, Laurent Nespoulous, and Jean-Paul Demoule

2016 Year 5 at Fukushima: A 'disaster-led' archaeology of the contemporary future. Antiquity 90 (350):409-424.

Sewell, William Henry

2005 Logics of History: Social Theory and Social Transformation. Chicago: University of Chicago Press.

Shiki, Tsunemasa, Yoshinobu Tsuji, Koji Minoura, and T. Yamazaki, eds.

2008 Tsunamiites: Features and Implications. Amsterdam: Elsevier.

SHimoyama, Satoru

1997 On the range of the disaster archaeology, in Hominids: 83-103. Tokyo: Congress of Reconstructing Archaeology.

Shimoyama, Satoru

$2002 a$ Basic characteristics of disasters, in Natural Disasters and Cultural Change: 19-27, ed. R. Torrence and J. Grattan. London: Routledge.

$2002 b$ Volcanic disasters and archaeological sites in southern Kyushu, Japan, in Natural Disasters and Cultural Change: 326-341, ed. R. Torrence and J. Grattan. London: Routledge.

Shinozaki, Tetsuya, Yuki Sawai, Junko Hara, Minoru Ikehara, Dan Matsumoto, and Koichiro TANIGAWA

2016 Geochemical characteristics of deposits from the 2011 Tohoku-oki tsunami at Hasunuma, Kujukuri coastal plain, Japan. Island Arc 25:350-368.

Shuto, Nobuo, and Koji Fujima

2009 A short history of tsunami research and countermeasures in Japan. Proceedings of the Japan Academy, Series B, 85(8):267-275.

Smithsonian Institution National Museum of Natural History

2013 Global volcanism program. URL: http://volcano.si.edu/learn_galleries.cfm?p=14.

TAPPIN, DAVID R.

2007 Sedimentary features of tsunami deposits - their origin, recognition and discrimination: An introduction. Sedimentary Geology 200(3-4):151-388.

2015 Tsunamis: Learning from recent events. Proceedings of the Open University Geological Society $1: 57-61$.

TEL (TSUnAmi ENGINEERING LABORATORY)

2016 Japan Tsunami Trace Database. Sendai: International Research Institute of Disaster Science, Tōhoku University. URL: http://tsunami-db.irides.tohoku.ac.jp/tsunami/mainframe.php? $\mathrm{LANG}=-2$.

Torrence, Robin, and John Grattan, eds.

2002 Natural Disasters and Cultural Change. London: Routledge. 
Watanabe, Masashi, Kazuhisa Goto, Fuminiko Imamura, and Chuki Hongo

2015 Numerical identification of tsunami boulders and estimation of local tsunami size at Ibaruma reef of Ishigaki Island, Japan. Island Arc 25(2016):316-332.

Yamada, Masaki, Shigehiro Fujino, James Goff, and Catherine Chagué-Goff

2016 Large-scale erosion and overbank deposition caused by the July 2013 flood of the Abu River, Yamaguchi City, Japan. Island Arc 25(5):386-399.

YAMAMOTO, MASAAKI

2012 Evidence of tsunami found at archaeological sites: Examination of the sites found around Karadake, Ishigaki Island. Kōkogaku Kenkyū 59(2):5-8. 